Article

\title{
Investigating the Potential Impact of Louisiana Coastal Restoration on the Trace Metal Geochemistry of Constructed Marshlands
}

\author{
Omolola A. Akintomide ${ }^{1, *}$, Segun A. Adebayo ${ }^{1}$, Alexandra S. Trahan ${ }^{2}$, \\ Elizabeth Chamberlain ${ }^{3,4,5}$ and Karen H. Johannesson ${ }^{1,6,7}$ \\ 1 Department of Earth and Environmental Sciences, Tulane University, New Orleans, LA 70118, USA; \\ sadebay@tulane.edu (S.A.A.); karen.johannesson@umb.edu (K.H.J.) \\ 2 School of Geosciences, The University of Louisiana at Lafayette, Lafayette, LA 70504, USA; \\ alextrahan9@gmail.com \\ 3 Department of Earth and Environmental Sciences, Vanderbilt University, Nashville, TN 37240, USA; \\ elizabeth.chamberlain@vanderbilt.edu \\ 4 Lamont Doherty Earth Observatory of Columbia University, Palisades, NY 10964, USA \\ 5 Netherlands Centre for Luminescence Dating, Wageningen University, 6708 PB Wageningen, \\ The Netherlands \\ 6 School for the Environment, University of Massachusetts Boston, Boston, MA 02125, USA \\ 7 Intercampus Marine Science Graduate Program, University of Massachusetts System, \\ Boston, MA 02125, USA \\ * Correspondence: oakintomide@tulane.edu
}

Received: 28 July 2020; Accepted: 3 September 2020; Published: 5 September 2020

\begin{abstract}
Coastal restoration through diversion of suspended sediments from the Lower Mississippi River (LMR) into hydrologically isolated marshlands of Mid-Barataria Bay and Mid-Breton Sounds in southern Louisiana has the potential to mobilize lead $(\mathrm{Pb})$, and other trace elements. We investigate the potential impact(s) of the diversion on marsh porewater through analysis of modern riverbank and suspended sediments, compared to sediments from pre-industrial deltaic deposits of LMR. Sequential extraction methods were used to evaluate $\mathrm{Pb}$, cobalt $(\mathrm{Co})$, copper $(\mathrm{Cu})$, nickel $(\mathrm{Ni})$, and zinc $(\mathrm{Zn})$ in the sediments. Our results show that metal contents are higher (e.g., 8- to 10-fold for $\mathrm{Pb}$ ) in the modern sediments relative to pre-industrial deposits. Also, the reducible fraction, presumably iron/manganese (Fe/Mn) oxides/oxyhydroxides, is the chief reservoir of environmentally available metals. The substantially higher trace metal contents of the modern relative to pre-industrial sediments suggest that the modern sediments contain a sizeable amount of anthropogenic contributions. Furthermore, the concentration of the trace metals in the reducible fraction suggests bioavailability to marsh organisms upon reductive dissolution within the planned, constructed coastal marshes. Still, additional sediment samples from the marshlands during the diversion implementation phase will be necessary to support the preliminary findings in this contribution as it affects coastal marshes and vital local fisheries.
\end{abstract}

Keywords: Trace metals; sequential extractions; contaminated sediment; wetlands/marshlands; Lower Mississippi River; diversions; redox conditions; Fe/Mn oxides/oxyhydroxides 


\section{Introduction}

Coastal areas like southern Louisiana are currently threatened by rising sea levels, increasing intensities of tropical cyclones and their associated storm surge, and land subsidence in sediment-starved locations (e.g., [1-7]). The combination of these processes has been met by building flood control structures as well as numerous coastal restoration projects (e.g., [8-17]). Developing innovative coastal management solutions is especially important in southern Louisiana where land loss within the coastal marshes has been severe (ca. $62 \mathrm{~km}^{2} \mathrm{a}^{-1}$ over the past 80 years) and is likely to continue due to a combination of factors including sea-level rise, land subsidence, and anthropogenic activities [18,19] even under the best management solutions [20]. For example, the extensive artificial levee system along the Mississippi River currently prevents deposition of river-borne sediments to the adjacent marshes, which under natural conditions maintains the marshlands and counters land subsidence. The coastal marshes of southern Louisiana are critically important for sustaining local fisheries, as the first line of defense against storm surge from tropical cyclones, and in preserving the unique cultural heritage of the region [7,21-24].

To combat land loss in the Lower Mississippi River (LMR) delta and associated coastal marshes, the Coastal Protection and Restoration Authority of Louisiana (CPRA) proposed a number of diversion projects within its comprehensive coastal master plan to restore marshlands and protect coastal areas [21,22]. Two of these diversion projects involve building gated control structures and outfall channels capable of diverting between ca. $1420 \mathrm{~m}^{3} / \mathrm{s}$ to ca. $2124 \mathrm{~m}^{3} / \mathrm{s}$ of Mississippi River water and suspended sediments during the maximum flow season (i.e., December to June) into the adjacent brackish marshlands of Mid-Barataria Bay and Mid-Breton Sound [25-28]. A 50-year model simulation of these proposed diversions estimated that the total cumulative suspended sand load, at different discharge configurations between $141 \mathrm{~m}^{3} / \mathrm{s}$ to $12,742 \mathrm{~m}^{3} / \mathrm{s}$, to the Mid-Breton Sound and Mid-Barataria Bay marshlands will be greater than 137 and 48 million tons, respectively [29]. Furthermore, if these marshlands are not protected from inundation, an estimated $1420 \mathrm{~km}^{2}$ of land will be lost in the next 50 years owing to the above-mentioned processes, with potentially dire consequences to the local communities, including the city of New Orleans [30].

Although it is widely accepted that the planned coastal restoration projects will be beneficial to the community and society at large in southern Louisiana, there are limited investigations into the possible impact of diverted river sediments on water quality of the local coastal marshes [31-33]. The Mississippi River drains 40 percent of the contiguous United States and delivers a sediment load of $210 \times 10^{6}$ tons per year into the Gulf of Mexico [34,35]. Previous investigations demonstrated that these river sediments carry a substantial lead $(\mathrm{Pb})$ load, and other potentially toxic trace metals like cadmium $(\mathrm{Cd})$, into the Gulf of Mexico that are subsequently deposited in the offshore sediments [36-38]. Although the $\mathrm{Pb}$ load of Mississippi River sediments has decreased since the reduction of leaded gasoline began in the USA during the late 1970s and was completely phased out by the mid-1990s [34,39], the legacy of industrial $\mathrm{Pb}$ in sediments and soils of numerous communities remain a substantial environmental and human health problem (e.g., [40-48]). The Mississippi River and its tributaries (e.g., the Ohio River and Missouri River) drains much of the industrial and agricultural heartland of the USA, which also includes a number of large metropolitan regions such as Minneapolis-St. Paul (Minnesota), St. Louis, and Kansas City (both in Missouri), Davenport (Iowa), Memphis (Tennessee), Cincinnati (Ohio), Pittsburg (Pennsylvania), as well as Baton Rouge and New Orleans in Louisiana. Consequently, soil/sediment $\mathrm{Pb}$ re-mobilized from these or other population centers along the Mississippi River, and its tributary still likely contributes $\mathrm{Pb}$ and other potentially toxic trace elements to the river system and the Gulf of Mexico. To the best of our knowledge, the possible fate and transport of these potentially toxic, river-transported metals once the river sediments are diverted into the coastal marshes along the LMR has not been investigated.

It is well known that estuaries and marshlands can act as traps for metals and other anthropogenic contaminants, and may provide long-term, natural storage of such compounds [49-54]. However, it is also possible for these metals to be mobilized from estuarine and marsh sediments if the environmental 
conditions change (e.g., changes in salinity, $\mathrm{pH}$, and/or redox conditions; [55-61]). Such changes could occur by natural processes like subsidence and associated flooding of coastal freshwater marshes by seawater, burial and accompanying anaerobic respiration, early diagenesis, or via anthropogenic modifications like dredging and disposal of dredge spoils. Indeed, studies have clearly shown that when sediments are dredged or diverted, biogeochemical reactions occur that can modify the chemical compositions, including the redox conditions of pore water at the new placement site $[32,33,62,63]$.

The chief sources of sediments to the planned Mid-Barataria Bay and Mid-Breton Sound diversions will be suspended sediments from the LMR, and perhaps some bed-load, both of which are currently transported by well-oxygenated Mississippi River water [21,22,64]. Consequently, possible effects of changing redox conditions on these sediments after deposition within the coastal marshes as they undergo early diagenesis driven, in part, by anaerobic respiration, necessitates careful investigation of the fate and transport of potentially toxic trace elements in these coastal marsh systems. Under the anaerobic redox conditions expected to predominate in these constructed marsh sediments (e.g., [33,65-68]), trace metals associated with reducible Fe(III)/Mn(IV) oxides/oxyhydroxides and/or oxidizable organic matter and sulfide minerals that are transported with the river sediments, could be mobilized into the marsh pore waters and possibly negatively impact marsh biota.

Although several studies have investigated the impact of the planned diversion projects on the LMR coastal marshes, these chiefly focused on sediment discharge, depositional dynamics, salinity gradients, nutrient accretion, and wetland restoration [69-74]. To our knowledge, none has explored the impact of changing redox conditions on trace metal mobilization as oxic river sediments are buried in the anaerobic, constructed coastal marshes. Here, we investigate the content of a number of potentially toxic trace metals (i.e., $\mathrm{Co}, \mathrm{Cu}, \mathrm{Ni}, \mathrm{Pb}$, and $\mathrm{Zn}$ ) in modern Mississippi River suspended sediments collected from the water column and modern river sediments deposited along the riverbank in New Orleans, Louisiana. We also examine the content of these trace metals from Late-Holocene-aged sedimentary deposits collected from a borehole near the proposed Mid-Barataria Bay diversion site [75] as local controls for pre-industrial metal loading to the environment. All of these sediments were also subjected to sequential extraction analysis to examine metal speciation between five, operationally defined fractions that include, weakly adsorbed and easily exchangeable metals, weak acid leachable metals associated with carbonate minerals, metals associated with reducible $\mathrm{Fe}(\mathrm{III}) / \mathrm{Mn}$ (IV) oxides/oxyhydroxides, metals associated with oxidizable organic matter and/or sulfide minerals, and the residual metals contained within the crystalline lattice of alumino-silicate minerals that make up the bulk of the sediments. The results of the geochemical analyses of these LMR sediments are then employed to infer possible anthropogenic sources (e.g., Pb), and hypothesize the fate and transport of these potentially toxic trace metals carried by the river suspended sediments after diversion and burial within the coastal marshes.

\section{Study Site}

The study area consists of sites across the LMR delta plain associated with the planned "land building" projects described in the Coastal Master Plan of Louisiana [21,22]. Specifically, Figure 1 shows the locations of two planned river diversions along the LMR that are located approximately $35 \mathrm{~km}$ southeast of New Orleans [28]. These include the Mid-Barataria Bay Diversion Site located to the west of the river and the Mid-Breton Sound Diversion Site further south and east (Figure 1). The estimated mean annual water discharge for the planned Mid-Barataria and Mid-Breton diversions are $67 \mathrm{~km}^{3} /$ year and $31 \mathrm{~km}^{3} /$ year, respectively [27]. The region of the Mississippi River where suspended river sediments and water will be diverted to these sites is also shown and labeled "Site 2" in Figure 1. The modern suspended river sediments analyzed in this contribution were collected from this location [76]; previous research has shown that silts are generally well mixed within the water column of the Mississippi River along this reach due to turbidity [77]. Mississippi River sediments were also collected from the modern riverbank deposits in New Orleans adjacent to Tulane University on an aggrading point bar of the river (Site 1; Figure 1), as well as from Late-Holocene-aged deltaic sedimentary deposits obtained from 
a borehole (Site 5) located southeast of New Orleans [75]. Sampling sites were selected to characterize past and present concentrations of potentially toxic trace metals in sediments of the LMR and to help infer anthropogenic metal loading compared to the probable natural background levels.

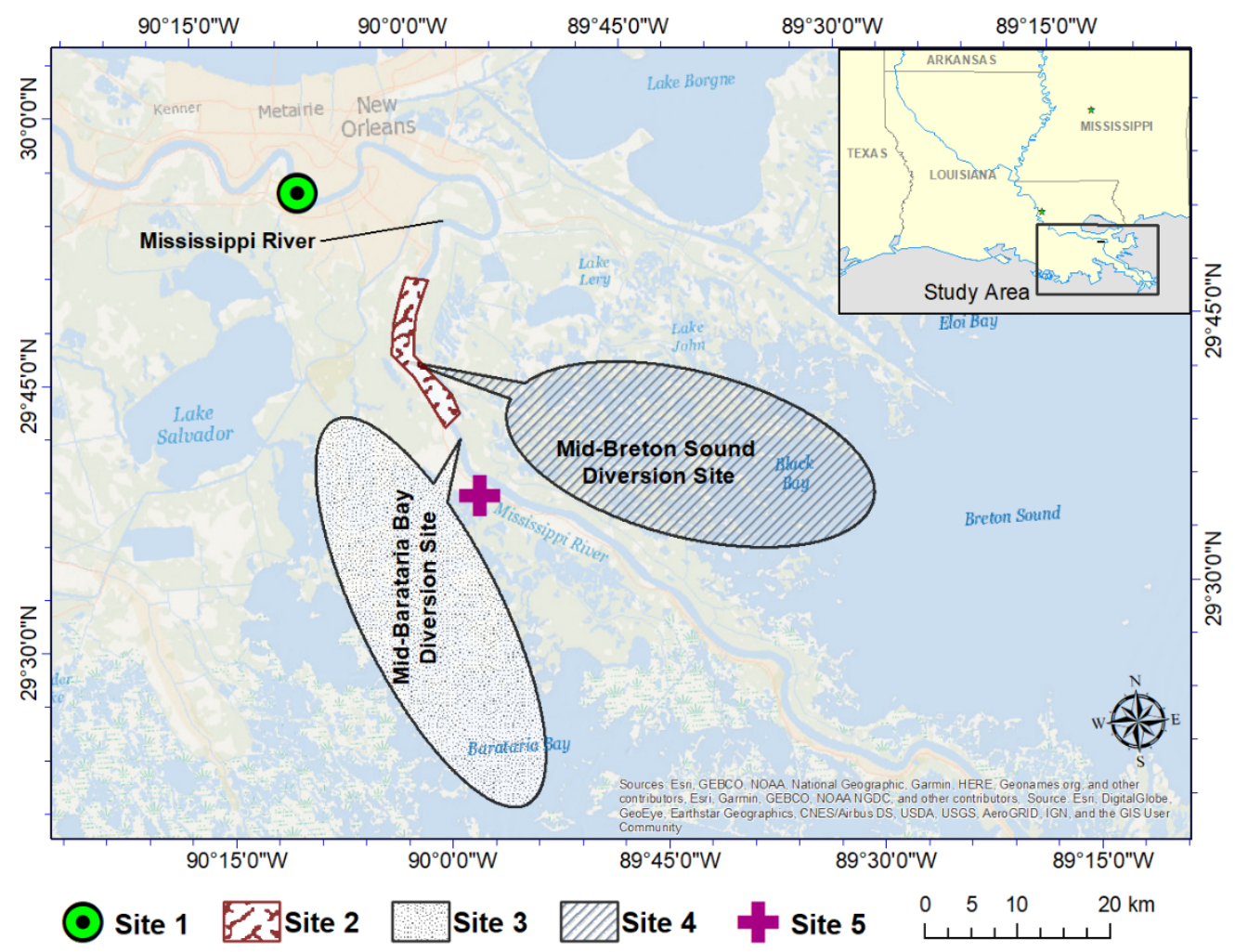

Figure 1. Map of the Lower Mississippi River delta showing the proposed diversion sites, and the sampling locations. Land is shown as yellow areas, whereas bodies of water are the blue regions. The sampling sites are located on the west and east side of the Lower Mississippi River (LMR) and deltaic plain: The green circle is Site 1 located at LMR bank near Tulane University. The light red polygon is Site 2, the proposed section of the LMR reach where suspended sediments will be diverted. The two polygons labeled "Mid-Barataria diversion" and "Mid-Breton diversion" are Site 3 and 4, respectively. The pink cross, Site 5 , is the location of the pre-industrial deltaic deposits. Base map from ArcGIS. Inset shows the location of the study area within the State of Louisiana, USA.

Shallow subsurface sediments of Barataria Bay and Breton Sound consists of unconsolidated organic-rich muds and peats (i.e., $>40 \%$ organic content; [78]) overlaying sand and silt beds $[79,80]$. The porosity of the marshland sediments is estimated to be $89 \pm 3 \%$ (see $[67,81])$ with the bulk sediment consisting of ca. $80 \%$ mud and ca. $20 \%$ sand $[25,28,74]$.

The proposed diversions that will feed new sediment to this region are slated for activation during periods of high suspended load, low saltwater intrusion, flooding, and high river discharge of about 28 to $7080 \mathrm{~m}^{3} / \mathrm{s}[22,74,82]$. The estimated average sediment load to be diverted onto the marshlands is between 1.5 to 2.3 million cubic meters per year, with a cumulative load of 76 to 115 million cubic meters in 50 years [83]. Currently, a detailed written Environmental Impact statement (EIS) is being prepared following the National Environmental Policy Act (NEPA) and Council on Environmental Quality (CEQ) regulations to analyze and disclose all possible significant impacts of the sediment diversion projects on the environment for permitting purposes [30]. The Mid-Barataria Bay and Mid-Breton Sound diversion projects are expected to commence after the completion of the environmental review and permitting process in the years 2023 and 2024, respectively [84,85]. The evaluation of both modern river sediments and Late-Holocene-aged sediments provide a means to investigate current metal loads of materials that will be diverted into the planned, brackish Mid-Barataria Bay and Mid-Breton Sound to help build 
new marshland because the former provides information on present-day metal concentrations and the latter provides control to gauge pre-industrial metal concentrations in the LMR sediments.

\section{Materials and Methods}

\subsection{Sample Collection}

Sediment samples were collected from three different locations; the Mississippi riverbank near Tulane University (Figure 1, Site 1), the section of the LMR reach that is proposed as the chief sediment source for both the Mid-Barataria Bay and the Mid-Breton Sound diversions (suspended river sediments; Figure 1, Site 2), and from undisturbed sandy layers at $\sim 5.4$ and $10.8 \mathrm{~m}$ depth within a borehole (Figure 1, Site 5). The riverbank deposits (more than $2 \mathrm{~kg}$ ) were obtained by grab sampling from the partly submerged riverbank into Ziplock ${ }^{\circledR}$ style polyethylene plastic bags in 2018 . The suspended sediments were collected from the LMR water column on 18 April 2014, a period of high river discharge and sediment load (see $[25,86]$; for details of suspended sediment sampling). Briefly, suspended sediments were collected using a P-6-200 point-integrative isokinetic sampler obtained from Carnet Technology in Terry, MS. Sampling followed the standard USGS suspended sediment method at five individual water depths (0, 0.3, 0.5, 0.7, and 0.9 fractions of the total water depth). Samples were collected in duplicate at each depth using one-liter bottles (e.g., [87]). After collection, water samples were first filtered using a $63 \mu \mathrm{m}$ sieve to separate the sand fraction, and then vacuum-filtered using $0.4 \mu \mathrm{m}$ polycarbonate filters (i.e., the "mud fraction"; $<63 \mu \mathrm{m}$ ). The filters containing the suspended sediments were then placed in airtight doubled polyethylene bags and stored at room temperature until analysis.

Late-Holocene-aged deltaic deposits were taken in 2017 from sandy units at $~ 5.4 \mathrm{~m}$ (TU 169, NCL-1217135) and $10.8 \mathrm{~m}$ (TU 171, NCL-1217137) depth within a hand-drilled borehole situated in a modern marsh near the proposed Mid-Barataria diversion site. These sand units have been previously dated to $\sim 1.3$ and $\sim 3.6 \mathrm{ka}$, respectively, and represent sediments deposited by past pathways of the Mississippi River [75]. The shallower sample is associated with the Balize (or, Plaquemines-Modern) lobe, and the deeper sample is associated with the St. Bernard lobe [75]. For a lobe chronology and synthesis of the Late Holocene evolution of the LMR delta, see Hijma et al. [88]. The sampled materials have not, to the best of our knowledge, been impacted by disturbances based on intact (not post-depositionally zeroed) luminescence signals and undisturbed stratigraphic layers within the borehole from which they were collected [75] and thus represent a pre-industrial baseline for trace metals in sediments of the LMR delta.

\subsection{Leaching Procedures and Reagents}

To investigate the speciation of $\mathrm{Pb}$ and the other potentially toxic trace elements (i.e., $\mathrm{Co}, \mathrm{Cu}$, $\mathrm{Ni}$, and $\mathrm{Zn}$ ) in the selected Mississippi River sediments, we subjected $0.5 \mathrm{~g}$ initial dry weight of each sample to the sequential extraction procedure (SEP) described by Tessier et al. [89], which is outlined in Table 1 . The four sediment samples were dried at $80^{\circ} \mathrm{C}$ in an air oven and then ground using an agate mortar and pestle to achieve homogeneity. These samples were also examined by $\mathrm{X}$-ray diffraction (XRD) to determine their mineral composition.

Regarding the sequential extraction procedure, the four sediment samples were leached with progressively stronger reagents designed to attack operationally defined fractions of the sediment, and the concentrations of $\mathrm{Co}, \mathrm{Cu}, \mathrm{Ni}, \mathrm{Pb}$, and $\mathrm{Zn}$ were measured in each leachate fraction (see Table $1 ;[63,90])$. The various reagents allow for the evaluation of potential trace element mobilization from the sediments owing to changes in $\mathrm{pH}$, redox conditions, and possibly salinity by extracting the environmentally labile fractions of each trace metal $[34,63]$. Specifically, the fractions targeted by the SEP include: the easily exchangeable surface adsorbed fraction (Fraction 1); the acid leachable fraction associated with carbonate minerals (Fraction 2); the reducible fraction associated with $\mathrm{Fe} / \mathrm{Mn}$ oxides/oxyhydroxides (Fraction 3); the oxidizable fraction associated with organic matter and possibly some sulfide minerals 
(Fraction 4); and the residual fraction associated with silicate and aluminosilicate minerals (Fraction 5; see Table 1). The first four fractions essentially target trace metals that are environmentally labile, which can be mobilized as environmental conditions change (e.g., changes in redox conditions, $\mathrm{pH}$, and salinity). Hence, the environmentally labile fractions of these trace metals are likely to be available to organisms (i.e., bioavailable) living in the sediments and/or associated pore waters. In contrast, trace elements associated with Fraction 5 are not environmentally mobile as they are considered to be contained within silicate mineral lattices [89].

Table 1. Details of the sequential extraction methods used to investigate trace element (TE) speciation in Mississippi River sediments. See Tessier et al. [89] for more details.

\begin{tabular}{|c|c|c|}
\hline Fraction & Reagent & Target Phase \\
\hline 1 & $1 \mathrm{M} \mathrm{CH}_{3} \mathrm{COONa}$; $\mathrm{HH} 8.2,1 \mathrm{~h}$ shaking $\left(25^{\circ} \mathrm{C}\right)$ & TE weakly adsorbed on mineral surfaces \\
\hline 2 & $1 \mathrm{M} \mathrm{CH}_{3} \mathrm{COONa}$ adjusted to $\mathrm{pH} 5$ with $\mathrm{CH}_{3} \mathrm{COOH}: 5$ h shaking $\left(25^{\circ} \mathrm{C}\right)$ & TE associated with carbonate minerals \\
\hline 3 & $0.04 \mathrm{M} \mathrm{NH}_{2} \mathrm{OH} \bullet \mathrm{HCl}$ in $25 \%(v / v) \mathrm{CH}_{3} \mathrm{COOH} ; 6$ h shaking $\left(96^{\circ} \mathrm{C}\right)$ & $\begin{array}{l}\text { TE associated with reducible Fe/Mn } \\
\text { oxides/oxyhydroxides }\end{array}$ \\
\hline 4 & $\begin{array}{l}0.02 \mathrm{M} \mathrm{HNO}_{3}+30 \% \mathrm{H}_{2} \mathrm{O}_{2} \text { adjusted to } \mathrm{pH} 2 \text { with } \mathrm{HNO}_{3} ; 5 \text { h shaking } \\
\left(85^{\circ} \mathrm{C}\right) \text {. Then } 3.2 \mathrm{M} \mathrm{CH}_{3} \mathrm{COONH}_{4} \text { in } 20 \% \mathrm{HNO}_{3} \text {; shaking for } 30 \text { min } \\
\left(25^{\circ} \mathrm{C}\right)\end{array}$ & $\begin{array}{l}\text { TE associated with oxidizable sedimentary organic } \\
\text { matter and some sulfide minerals }\end{array}$ \\
\hline 5 & $\begin{array}{l}\text { Concentrated } \mathrm{HNO}_{3} \text { and } \mathrm{HF} \text { (heated to near dryness and re-dissolved } \\
\text { in } 2 \% \mathrm{HNO}_{3}\end{array}$ & TE within the crystalline structure of silicate minerals \\
\hline
\end{tabular}

The resultant solutions from each successive extraction were separated at $3000 \mathrm{rpm}$ and $1950 \mathrm{RCF}$ by centrifugation (IEC Centra $\mathrm{Cl}_{2}{ }^{\circledR}$ ) for 10 mins. The supernatant (or leachate) was decanted into a $25 \mathrm{~mL}$ bottle, acidified with ultrapure nitric acid $\left(\mathrm{HNO}_{3}\right)$ to bring the $\mathrm{pH}$ below 2, and then stored at a temperature of $4{ }^{\circ} \mathrm{C}$ until analysis to avoid the re-adsorption of constituents to the sediments or container walls. After each extraction, the residual sediment was rinsed with $8 \mathrm{~mL}$ of ultrapure deionized water (i.e., $18.2 \mathrm{M} \Omega \mathrm{cm}$ ) from a Millipore Element water system (hereafter Q-water) and centrifuged for $10 \mathrm{~min}$. Then, the second supernatant was discarded to remove any reagent left in the residue before use in the next leaching step. Note that the residue from the previous step served as the leach solid for the next extraction.

\subsection{Total Digestion of Sediment Samples}

In addition to the sequential extractions, aliquots of each sediment samples were digested entirely to determine their total contents of $\mathrm{Co}, \mathrm{Cu}, \mathrm{Ni}, \mathrm{Pb}$, and $\mathrm{Zn}$. The total sediment digestions were also used to check the recovery of the sequential extractions, which, when added together, should be equal to the total sediment content for each trace element. Here, $0.2 \mathrm{~g}$ initial dry weight of the four sediment samples were digested in separate $50 \mathrm{~mL}$ Teflon ${ }^{\circledR}$ beakers (with lid; Savillex, Eden Prairie, MN) using $10 \mathrm{~mL}$ of trace metal grade $\mathrm{HF}$ and $10 \mathrm{~mL}$ of trace metal grade $\mathrm{HNO}_{3}$. The sediment-solution slurry was heated until near dryness, and the resulting residue was re-dissolved in $2 \%(v / v)$ ultrapure (Optima ${ }^{\mathrm{TM}}$ grade) $\mathrm{HNO}_{3}$ and then diluted up to $25 \mathrm{~mL}$ with ultrapure Q-water. All labware used for experimental analysis was previously cleaned with reagent grade $\mathrm{HNO}_{3}$, followed by trace metal grade $\mathrm{HNO}_{3}$, and rinsed with Q-water. The reagents used were all trace metal grade or Optima ${ }^{\mathrm{TM}}$ grade to avoid possible metal contamination.

\subsection{Analytical Methods}

The concentrations of $\mathrm{Co}, \mathrm{Cu}, \mathrm{Ni}, \mathrm{Pb}$, and $\mathrm{Zn}$ in the sequential leachates and total sediment digestions were analyzed by sector-field inductively coupled plasma mass spectrometry (ICP-MS; Thermo Fisher Element 2) at Tulane University. The leachates for all fractions and sample types were diluted with Q-water within the ICP-MS's linear working range (i.e., factors of 10 and 100) because each metal was present at high concentrations in the leach solutions. This ensures that the concentration of each targeted trace element in the diluted sample is within this linear working range of $1 \mathrm{ng} / \mathrm{L}$ to $10 \mathrm{ng} / \mathrm{L}$ for this ICP-MS. 
Before loading the diluted samples, the ICP-MS sampler was rinsed with Q-water, followed by sequence control $2 \%$ nitric acid blanks. The ICP-MS was calibrated for each trace element using a calibration curve made up of eight calibration standards (e.g., concentrations of $0.5 \mu \mathrm{g} / \mathrm{L}, 1 \mu \mathrm{g} / \mathrm{L}$, $10 \mu \mathrm{g} / \mathrm{L}, 25 \mu \mathrm{g} / \mathrm{L}, 50 \mu \mathrm{g} / \mathrm{L}, 125 \mu \mathrm{g} / \mathrm{L}, 250 \mu \mathrm{g} / \mathrm{L}$, and $500 \mu \mathrm{g} / \mathrm{L}$ ) prepared from a $10 \mathrm{mg} / \mathrm{L} \mathrm{Spex} \mathrm{CertiPrep}{ }^{\circledR}$ multi-element 2 calibration standard. In addition, each sample aliquot was spiked with $10 \mu \mathrm{g} / \mathrm{L}$ of a single-element scandium solution as an internal standard for monitoring instrument drift. Subsequently, every batch of the diluted sample solutions was run at low, medium, and high resolutions to measure the trace element concentrations and minimize the polyatomic, oxide/hydroxide, and other possible mass interferences. The detection limits were below $1 \mu \mathrm{g} / \mathrm{L}$ for $\mathrm{Pb}, \mathrm{Cu}, \mathrm{Zn}, \mathrm{Ni}$, and $\mathrm{Co}$, and above $1 \mathrm{mg} / \mathrm{L}$ for $\mathrm{Fe}, \mathrm{Al}, \mathrm{Mg}, \mathrm{K}, \mathrm{Ca}$, and Ba in extracted solutions.

\section{Results}

Concentrations (in $\mathrm{mg} / \mathrm{kg}$ of the dry weight of sediment sample $=\mathrm{mg} / \mathrm{L}$ ) of $\mathrm{Co}, \mathrm{Cu}, \mathrm{Ni}, \mathrm{Pb}$, and $\mathrm{Zn}$ in the sequential extracts of the pre-industrial sedimentary deposits (i.e., samples TU 169 and TU 171), modern Mississippi River suspended sediment (MRSS), and the modern Mississippi riverbank sedimentary deposits (MRBS) are presented in Table 2 along with their concentrations from the total sediment digestion analysis. Differences between the summation of all five sequential extractions of each sediment sample and the results of the total digestion analyses are in good agreement, with recoveries of each trace metals in the sequential extractions ranging between $95 \%$ and $104 \%$ of the total digestion values (Table 2), and exhibiting a mean $\pm 1 \sigma$ recovery of $100.4 \pm 3.44 \%$ (Table 2 ). The concentrations of these trace metals in the five sequential extracts of the examined LMR sediments are presented graphically in Figure 2. In Table A1 (see Appendix A), we present the relative amount of $\mathrm{Co}, \mathrm{Cu}, \mathrm{Ni}, \mathrm{Pb}$, and $\mathrm{Zn}$ determined in each sequential extract as a percent of the total content of each metal in the LMR sediment samples. The relative amounts (as percentages) of total individual metal contents of the sequential extractions are also graphically depicted in Figure A1 (see Appendix A). The mineral composition of the Mississippi River sediments from the XRD analysis are also presented in Table A2 and Figure A2 (see Appendix A). Based on the pre- and post-dissolution quantitative XRD results, the MRBS sediment consists mostly of quartz $(\sim 77-83 \%)$, microcline $(12-22 \%)$, albite $(\sim 4.3 \%$. post-dissolution XRD only) with traces of mica and clay minerals (Appendix A).

The modern suspended sediment sample from the Mississippi River water column exhibits the highest contents of all five trace metals of the sediments analyzed, whereas the Late-Holocene-aged sediments collected from buried pre-industrial deltaic sands exhibit the lowest contents of these metals (Figure 2). The sequential extraction analysis indicates that the degree of environmental lability of metals in the LMR suspended sediments follows the order: $\mathrm{Pb}>\mathrm{Cu}>\mathrm{Co}>\mathrm{Zn}>\mathrm{Ni}$ (Tables 3 and A1; Figure A1). Moreover, the total $\mathrm{Pb}$ content of the modern suspended sediment sample $(50.9 \mathrm{mg} / \mathrm{kg})$ is between 7.9 and 9.7 times higher than the total $\mathrm{Pb}$ content measured in the pre-industrial deposits (5.26 and $6.48 \mathrm{mg} / \mathrm{kg}$ ) and 4-fold higher than the $\mathrm{Pb}$ content of the modern riverbank deposits (MRBS; $12.7 \mathrm{mg} / \mathrm{kg}$; Table 2). A remarkable feature of the $\mathrm{Pb}$ data, however, is that the amount contained within the residual fraction (i.e., aluminosilicate minerals) is similar for all four sediment samples analyzed (Figure 2). Specifically, the $\mathrm{Pb}$ content of the residual fraction of the modern suspended sediments $(7.91 \mathrm{mg} / \mathrm{kg}$ ) is within a factor of 2 of the residual $\mathrm{Pb}$ content of the pre-industrial deltaic sand deposits ( 4.1 and $5.1 \mathrm{mg} / \mathrm{kg}$ ) and is nearly identical to the $\mathrm{Pb}$ content of the residual fraction of the modern riverbank sediment $(6.39 \mathrm{mg} / \mathrm{kg}$; Table 2; Figure 2). This finding underscores the importance of the environmentally labile $\mathrm{Pb}$ content of Mississippi River suspended sediments. 

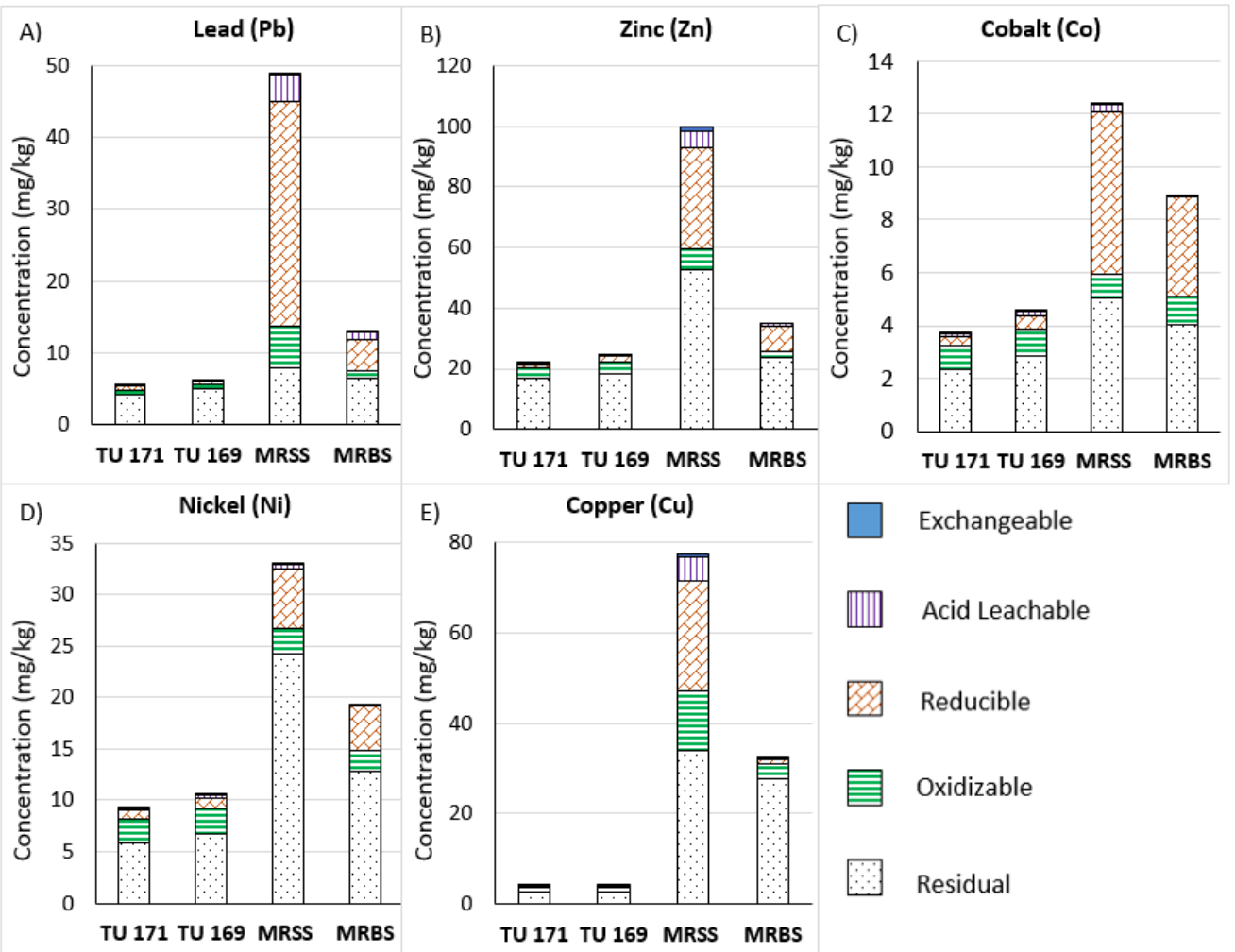

$\square$ Exchangeable

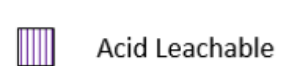

Reducible

Oxidizable

Residual

Figure 2. Concentrations of trace elements in sequential leachates of sediments from the LMR. Panels (A-E) present results for $\mathrm{Pb}, \mathrm{Zn}, \mathrm{Co}, \mathrm{Ni}$, and $\mathrm{Cu}$, respectively, in $\mathrm{mg} / \mathrm{kg}$ of dry weight total sediment. TU 171 is the older ( 3.6 ka) and TU 169 is the younger $(\sim 1.3 \mathrm{ka})$ of the pre-industrial deltaic deposits, whereas the Mississippi River suspended sediment (MRSS) and Mississippi riverbank sedimentary deposits (MRBS) are modern sediments of the LMR. Note, that the concentration ranges on each panel differ.

The distribution of $\mathrm{Pb}$ in the five sequential extractions of the MRSS sample follows the order: reducible $(31.3 \mathrm{mg} / \mathrm{kg})>\operatorname{residual}(7.91 \mathrm{mg} / \mathrm{kg})>$ oxidizable $(5.77 \mathrm{mg} / \mathrm{kg})>$ acid leachable $(3.71 \mathrm{mg} / \mathrm{kg})$ $>$ exchangeable $(0.03 \mathrm{mg} / \mathrm{kg}$; Tables 2 and 3; Figure 2A), which represents $64.2 \%, 16.3 \%, 11.9 \%, 7.64 \%$, and $0.06 \%$, respectively, of the total $\mathrm{Pb}$ content of this sample (Table A1). This distribution also emphasizes the importance of the environmentally labile fraction of $\mathrm{Pb}$ in Mississippi River suspended sediments, and in particular, the reducible fraction of $\mathrm{Pb}$. Specifically, our analyses indicate that the vast majority of $\mathrm{Pb}$ transported by suspended sediment in the Mississippi River is associated with microbially reducible $\mathrm{Fe}(\mathrm{III}) / \mathrm{Mn}(\mathrm{IV})$ oxides/oxyhydroxides, which is in agreement with earlier investigations of suspended sediment in the river $[37,91]$. In a similar fashion, about $33 \%$ of the environmentally labile $\mathrm{Pb}$ in the modern riverbank sediment is also associated with $\mathrm{Fe} / \mathrm{Mn}$ oxides/oxyhydroxides. In contrast, the majority of the environmentally labile $\mathrm{Pb}$ in the pre-industrial deltaic deposits obtained from the borehole $(8-14 \%)$ are associated with the oxidizable fractions of these sediments, which presumably represent sedimentary organic matter (Figure A1). 
Table 2. Concentrations of metals in the 5-phase sequentially extracted solutions. Shown are the concentrations \pm the analytical error of each analysis in mg/kg.

\begin{tabular}{|c|c|c|c|c|c|c|c|c|c|}
\hline Metal & $\begin{array}{l}\text { Sample } \\
\text { No. }\end{array}$ & $\begin{array}{l}\text { Fraction } 1 \\
\left(\mathrm{mg} \mathrm{kg}^{-1}\right)\end{array}$ & $\begin{array}{l}\text { Fraction } 2 \\
\left(\mathrm{mg} \mathrm{kg}^{-1}\right)\end{array}$ & $\begin{array}{l}\text { Fraction } 3 \\
\left(\mathrm{mg} \mathrm{kg}^{-1}\right)\end{array}$ & $\begin{array}{l}\text { Fraction } 4 \\
\left(\mathrm{mg} \mathrm{kg}^{-1}\right)\end{array}$ & $\begin{array}{l}\text { Fraction } 5 \\
\left(\mathrm{mg} \mathrm{kg}^{-1}\right)\end{array}$ & $\begin{array}{l}\text { Sum of Fractions } \\
\quad\left(\mathrm{mg} \mathrm{kg}^{-1}\right)\end{array}$ & $\begin{array}{l}\text { Total Sediment Digestion } \\
\qquad\left(\mathrm{mg} \mathrm{kg}^{-1}\right)\end{array}$ & $\begin{array}{l}\text { Recovery } \\
\text { (\%) }\end{array}$ \\
\hline \multirow{4}{*}{$\mathrm{Pb}$} & TU 171 & $0.01^{\mathrm{a}}$ & $0.12^{\mathrm{a}}$ & $0.48 \pm 0.14$ & $0.76^{\mathrm{a}}$ & $4.1 \pm 0.16$ & 5.47 & $5.26 \pm 0.15$ & 104 \\
\hline & TU 169 & $\mathrm{~b}$ & $0.17 \pm 0.01$ & $0.42 \pm 0.02$ & $0.51 \pm 0.05$ & $5.1 \pm 0.20$ & 6.19 & $6.48 \pm 0.05$ & 96 \\
\hline & MRSS & $0.03^{\mathrm{a}}$ & $3.71 \pm 0.10$ & $31.3 \pm 0.53$ & $5.77 \pm 0.17$ & $7.91 \pm 0.68$ & 48.7 & $50.9 \pm 0.56$ & 96 \\
\hline & MRBS & $0.00^{\mathrm{a}}$ & $0.99 \pm 0.09$ & $4.26 \pm 0.03$ & $1.20^{\mathrm{a}}$ & $6.39 \pm 0.05$ & 13.4 & $12.7 \pm 0.31$ & 106 \\
\hline \multirow{4}{*}{$\mathrm{Zn}$} & TU 171 & $0.05^{\mathrm{a}}$ & $0.60 \pm 0.01$ & $1.14 \pm 0.07$ & $3.15 \pm 0.32$ & $17.0 \pm 0.77$ & 21.9 & $20.8 \pm 0.81$ & 105 \\
\hline & TU 169 & $0.04^{\mathrm{a}}$ & $0.36 \pm 0.03$ & $1.59 \pm 0.14$ & $3.93 \pm 0.3$ & $18.5 \pm 0.5$ & 24.4 & $24.9 \pm 0.40$ & 98 \\
\hline & MRSS & $1.80 \pm 0.01$ & $5.05 \pm 0.18$ & $33.4 \pm 0.73$ & $6.97 \pm 0.21$ & $52.8 \pm 1.16$ & 100.0 & $105 \pm 2.30$ & 95 \\
\hline & MRBS & $\mathrm{b}$ & $1.28 \pm 0.03$ & $8.07 \pm 0.08$ & $2.03 \pm 0.08$ & $23.7 \pm 0.17$ & 35.3 & $36.4 \pm 0.34$ & 97 \\
\hline \multirow{4}{*}{ Co } & TU 171 & $0.03^{\mathrm{a}}$ & $0.15^{\mathrm{a}}$ & $0.35 \pm 0.02$ & $0.89 \pm 0.02$ & $2.35 \pm 0.05$ & 3.74 & $3.79 \pm 0.07$ & 99 \\
\hline & TU 169 & $0.03^{\mathrm{a}}$ & $0.14 \pm 0.02$ & $0.52 \pm 0.03$ & $1.05 \pm 0.10$ & $2.82 \pm 0.11$ & 4.55 & $4.69 \pm 0.05$ & 97 \\
\hline & MRSS & $0.02^{\mathrm{a}}$ & $0.28^{\mathrm{a}}$ & $6.11 \pm 0.23$ & $0.92 \pm 0.03$ & $5.04 \pm 0.24$ & 12.4 & $11.9 \pm 0.27$ & 104 \\
\hline & MRBS & $0.01^{\mathrm{a}}$ & $0.03^{\mathrm{a}}$ & $3.78 \pm 0.08$ & $1.05 \pm 0.02$ & $4.03 \pm 0.11$ & 8.90 & $8.88 \pm 0.20$ & 100 \\
\hline \multirow{4}{*}{$\mathrm{Ni}$} & TU 171 & $0.02^{a}$ & $0.22^{a}$ & $0.86 \pm 0.05$ & $2.22 \pm 0.08$ & $5.93 \pm 0.21$ & 9.25 & $8.97 \pm 0.54$ & 103 \\
\hline & TU 169 & $0.02^{\mathrm{a}}$ & $0.22 \pm 0.01$ & $1.01 \pm 0.05$ & $2.41 \pm 0.18$ & $6.79 \pm 0.12$ & 10.5 & $10.1 \pm 0.29$ & 104 \\
\hline & MRSS & $0.16^{\mathrm{a}}$ & $0.44 \pm 0.02$ & $5.84 \pm 0.14$ & $2.46 \pm 0.08$ & $24.2 \pm 0.34$ & 33.1 & $32.3 \pm 0.84$ & 103 \\
\hline & MRBS & $\mathrm{b}$ & $0.15^{\mathrm{a}}$ & $4.34 \pm 0.10$ & $2.00 \pm 0.05$ & $12.9 \pm 0.44$ & 19.4 & $19.4 \pm 0.19$ & 100 \\
\hline \multirow{4}{*}{$\mathrm{Cu}$} & TU 171 & $0.03^{\mathrm{a}}$ & $0.14^{\mathrm{a}}$ & $0.16^{\mathrm{a}}$ & $0.87 \pm 0.04$ & $2.88 \pm 0.13$ & 4.07 & $4.01 \pm 0.28$ & 102 \\
\hline & TU 169 & $0.02^{\mathrm{a}}$ & $0.12 \pm 0.02$ & $0.21 \pm 0.02$ & $0.80 \pm 0.03$ & $2.81 \pm 0.18$ & 3.95 & $4.02 \pm 0.33$ & 98 \\
\hline & MRSS & $0.55 \pm 0.01$ & $5.45 \pm 0.01$ & $24.3 \pm 0.34$ & $13.2 \pm 0.13$ & $33.9 \pm 1.53$ & 77.4 & $79.0 \pm 1.03$ & 98 \\
\hline & MRBS & $0.06^{\mathrm{a}}$ & $0.32 \pm 0.01$ & $1.20 \pm 0.02$ & $3.05 \pm 0.07$ & $27.8 \pm 0.61$ & 32.5 & $31.7 \pm 0.76$ & 103 \\
\hline
\end{tabular}

${ }^{\mathrm{a}}$ Concentrations lacking an associated error indicate that the analytical errors for these analyses were less than $\pm 0.01 \mathrm{mg} / \mathrm{kg} .{ }^{\mathrm{b}}$ Below detection limit.

Table 3. Summary of metal affinities in bioavailable fractions ${ }^{b}$ using the percentage distribution of concentration from Table A1.

\begin{tabular}{ccccc}
\hline Fraction & Oldest Pre-Industrial Deposits & Youngest Pre-Industrial Deposits & MRSS & MRBS \\
\hline \multirow{2}{*}{1} & $\mathrm{Co}>\mathrm{Cu}>\mathrm{Ni}>\mathrm{Zn}>\mathrm{Pb}$ & $\mathrm{Co}>\mathrm{Cu}>\mathrm{Ni}>\mathrm{Zn}$ & $\mathrm{Zn}>\mathrm{Cu}>\mathrm{Ni}>\mathrm{Co}>\mathrm{Pb}$ & $\mathrm{Cu}>\mathrm{Co}>\mathrm{Pb}$ \\
& $(0.69)(0.59)(0.24)(0.2)(0.12)$ & $(0.57)(0.43)(0.20)(0.15)$ & $(1.7)(0.70)(0.48)(0.13)(0.06)$ & $(0.18)(0.03)(0.02)$ \\
\hline \multirow{2}{*}{2} & $\mathrm{Co}>\mathrm{Cu}>\mathrm{Zn}>\mathrm{Ni}>\mathrm{Pb}$ & $\mathrm{Co}>\mathrm{Cu}>\mathrm{Pb}>\mathrm{Ni}>\mathrm{Zn}$ & $\mathrm{Cu}>\mathrm{Pb}>\mathrm{Zn}>\mathrm{Co}>\mathrm{Ni}$ & $\mathrm{Pb}>\mathrm{Co}>\mathrm{Zn}>\mathrm{Ni}>\mathrm{Cu}$ \\
& $(3.9)(3.3)(2.7)(2.4)(2.23)$ & $(3.3)(2.9)(2.7)(2.2)(1.5)$ & $(7.6)(6.9)(5.0)(2.25)(1.33)$ & $(7.7)(3.6)(0.99)(0.76)(0.33)$ \\
\hline \multirow{2}{*}{3} & $\mathrm{Ni}>\mathrm{Co}>\mathrm{Pb}>\mathrm{Zn}>\mathrm{Cu}$ & $\mathrm{Co}>\mathrm{Ni}>\mathrm{Pb}>\mathrm{Zn}>\mathrm{Cu}$ & $\mathrm{Pb}>\mathrm{Co}>\mathrm{Zn}>\mathrm{Cu}>\mathrm{Ni}$ & $\mathrm{Co}>\mathrm{Pb}>\mathrm{Zn}>\mathrm{Ni}>\mathrm{Cu}$ \\
& $(9.3)(9.1)(8.8)(5.2)(3.7)$ & $(11.3)(9.7)(6.7)(6.5)(5.1)$ & $(64)(49)(33)(31)(18)$ & $(42.0)(33.0)(22.8)(22.4)(3.69)$ \\
\hline \multirow{2}{*}{4} & $\mathrm{Ni}>\mathrm{Co}>\mathrm{Cu}>\mathrm{Zn}>\mathrm{Pb}$ & $\mathrm{Ni}>\mathrm{Co}>\mathrm{Cu}>\mathrm{Zn}>\mathrm{Pb}$ & $\mathrm{Cu}>\mathrm{Pb}>\mathrm{Ni}>\mathrm{Co}>\mathrm{Zn}$ & $\mathrm{Co}>\mathrm{Ni}>\mathrm{Cu}>\mathrm{Pb}>\mathrm{Zn}$ \\
& $(24)(23.7)(20.1)(14.4)(14)$ & $(23.1)(23)(19.7)(16.1)(8.2)$ & $(16.8)(11.9)(7.4)(7.3)(7)$ & $(11.8)(10.3)(9.4)(9.3)(5.7)$ \\
\hline
\end{tabular}


Copper and $\mathrm{Zn}$ exhibit broadly similar distributions between the sediments to that $\mathrm{Pb}$. For example, the total $\mathrm{Cu}$ content of modern LMR suspended sediments $(79 \mathrm{mg} / \mathrm{kg})$ is nearly 20 -fold higher than found in the two pre-industrial sandy deposits $(4 \mathrm{mg} / \mathrm{kg})$, and a factor of 2.5 higher than measured in the modern riverbank deposits $(31.7 \mathrm{mg} / \mathrm{kg})$, whereas $\mathrm{Zn}$ is between 4 -fold and 5 -fold higher in the modern suspended sediments $(105 \mathrm{mg} / \mathrm{kg})$ than in the ancient deposits (20.8 and $24.9 \mathrm{mg} / \mathrm{kg}$ ), and about three times higher than in the modern riverbank deposits ( $36.4 \mathrm{mg} / \mathrm{kg}$; Table 2; Figure 2). Unlike $\mathrm{Pb}$, however, the $\mathrm{Cu}$ and $\mathrm{Zn}$ contents of the residual fraction of each sediment vary considerably, with the $\mathrm{Cu}$ content of the residual fraction of the suspended sediment $(33.9 \mathrm{mg} / \mathrm{kg})$ being 12 times higher than in the residual fraction of the pre-industrial sandy deposits ( 2.81 and $2.88 \mathrm{mg} / \mathrm{kg})$, and the $\mathrm{Zn}$ content of the residual fraction of the modern suspended sediment $(52.8 \mathrm{mg} / \mathrm{kg})$ being roughly 3-fold higher than in the pre-industrial sandy deposits (17 and $18.5 \mathrm{mg} / \mathrm{kg}$; Table 2). Furthermore, the relative amount of environmentally labile $\mathrm{Cu}$ and $\mathrm{Zn}$ associated with the modern river suspended sediment (i.e., $55.1 \%$ and $47.2 \%$, respectively) is substantially less than for that of $\mathrm{Pb}$ (83.8\%; Table A1; Figure A1).

The residual fraction accounts for the majority of the $\mathrm{Cu}$ in the LMR sediments, except for the Mississippi River suspended sediment (MRSS), where slightly more than half of the total $\mathrm{Cu}(55.1 \%)$ occurs in various environmentally labile forms, with the reducible fraction accounting for the majority of the environmentally labile $\mathrm{Cu}$. More specifically, the distribution of $\mathrm{Cu}$ in the MRSS sample decreases in the order: residual $(33.9 \mathrm{mg} / \mathrm{kg})>$ reducible $(24.3 \mathrm{mg} / \mathrm{kg})>$ oxidizable $(13.2 \mathrm{mg} / \mathrm{kg})>$ acid leachable $(5.45 \mathrm{mg} / \mathrm{kg})>$ exchangeable $(0.55 \mathrm{mg} / \mathrm{kg}$; Table 2$)$, which represents $42.9 \%, 30.7 \%, 16.8 \%$, $6.9 \%$, and $0.7 \%$, respectively, of the total $\mathrm{Cu}$ content of the suspended sediment sample. In contrast, about $67 \%$ of the total $\mathrm{Cu}$ content of the pre-industrial deposits and more than $85 \%$ of the total $\mathrm{Cu}$ in the MRBS is associated with the residual fraction. Most of the remaining $\mathrm{Cu}$ in the pre-industrial deposits (ca. 20\%) occurs in the oxidizable fraction, whereas the relative amounts of $\mathrm{Cu}$ in exchangeable, acid leachable, reducible, and oxidizable fractions together amount to less than $15 \%$ of the total $\mathrm{Cu}$ in the MRBS sample. The majority of the $\mathrm{Zn}$ also occurs in the residual fraction of all the sediments studied, including the modern suspended sediments (see Figure A1). Apart from the residual fraction, the oxidizable fraction dominates the environmentally labile $\mathrm{Zn}$ portions in the pre-industrial deposits (ca. 14 to 16\%), whereas the reducible fraction dominates in the MRSS (ca. 33.4\%) and MRBS (ca. 22.8\%) samples (Table A1; Figure A1). For all samples, the percentage distribution of $\mathrm{Zn}$ in the exchangeable and acid leachable is below $7 \%$.

The modern suspended sediment also exhibits much higher contents of $\mathrm{Co}$ and $\mathrm{Ni}(11.9 \mathrm{mg} / \mathrm{kg}$ and $32.3 \mathrm{mg} / \mathrm{kg}$, respectively) compared to the pre-industrial deposits (i.e., on average 2.8- and 3.4-fold higher, respectively). However, the $\mathrm{Co}$ and $\mathrm{Ni}$ contents of the modern riverbank sediments (i.e., MRBS, $8.88 \mathrm{mg} / \mathrm{kg}$, and $19.4 \mathrm{mg} / \mathrm{kg}$, respectively) are only 1.3 and 1.7 times lower, respectively, than in the modern suspended sediments (Table 2, Figure 2). Most of the Ni is associated with the residual fraction $(64-73 \%)$, whereas between $41 \%$ and $63 \%$ of the Co is associated with the environmentally labile fractions of each sediment sample, and in particular, the reducible (Fraction 3) and oxidizable (Fraction 4) pools of these sediments (Table A1, Figure A1). Specifically, the Co content was roughly equally distributed between the residual and reducible fractions in the modern suspended sediments and the modern riverbank deposits. In terms of the environmentally labile fractions of $\mathrm{Ni}$, the oxidizable fraction dominates in the pre-industrial deposits, whereas the reducible fraction dominates in both the MRSS and MRBS. The exchangeable and acid leachable Ni fractions together account for less than $3 \%$ of the non-residual $\mathrm{Ni}$ in all of the sediment samples.

\section{Discussion}

\subsection{Comparison with Previous Studies}

A summary of historical trace metal data from sediments of the LMR relevant to our study is presented in Table 4 . These data include analyses of suspended sediments, delta plain sediments, 
and pre-industrial sediments collected from offshore. The offshore pre-industrial sediment consists of the average of six samples from a long sediment core with ages greater than ca. 800 years before present [92]. The $\mathrm{Pb}$ and $\mathrm{Cu}$ content of the LMR suspended sediment sample we analyzed (i.e., MRSS) are slightly higher than those reported previously for suspended sediments collected in the mid-1970s by Trefry and co-workers, whereas the $\mathrm{Zn}, \mathrm{Co}$, and Ni contents are lower in our sample (i.e., MRSS; Tables 2 and 4). Although the Pb content is only slightly higher (ca. 1.2 times higher) than these early measurements, the $\mathrm{Cu}$ content is nearly 2 -fold higher in the MRSS sample. These observations could be of concern because the majority of measurements indicate a decline in $\mathrm{Pb}$ content between the mid-1970s and the early- to mid-1980s and early 1990s (i.e., from ca. $45 \mathrm{mg} / \mathrm{kg}$ to $32 \mathrm{mg} / \mathrm{kg}$; [34,93]). This decrease in $\mathrm{Pb}$ content was attributed to the elimination of leaded gasoline in the USA [34].

The $\mathrm{Pb}$ content we measured in the modern LMR suspended sediment sample (i.e., $50.9 \mathrm{mg} / \mathrm{kg}$ ) is, however, similar to values determined for the "colloidal" fraction of suspended sediment (i.e., $38-49 \mathrm{mg} / \mathrm{kg}$ ) collected from below Belle Chase, Louisiana [64]. These authors define the "colloidal" fraction as passing through a $1 \mu \mathrm{m}$ pore-size filter and the "suspended silt" fraction of the suspended sediment as ranging in size from $1 \mu \mathrm{m}$ to $150 \mu \mathrm{m}$ [64]. In addition to exhibiting higher $\mathrm{Pb}$ contents, their "colloidal" fraction is also enriched in $\mathrm{Zn}$ and $\mathrm{Cu}$ compared to their "suspended silt" fraction (Table 4). We used $0.4 \mu \mathrm{m}$ pore-size filters to capture suspended sediments from the Mississippi River waters in this contribution. Hence, our sample (MRSS) contains at least a portion of the "colloidal" size fraction analyzed by Piper et al. [64], as well as any particles of greater size. The combination of inclusion of the "colloids" pool and particulate matter up to $63 \mu \mathrm{m}$ may, in part, explain the higher $\mathrm{Pb}$ content we determined for MRSS compared to the study by Piper et al. [64]. The $\mathrm{Cu}$ content of the "colloidal" fraction reported by these authors (i.e., $62-72 \mathrm{mg} / \mathrm{kg}$ ) is actually quite similar to the $\mathrm{Cu}$ content we determined in the MRSS sample (79 mg/kg; Tables 2 and 4), suggesting that the $\mathrm{Cu}$ and perhaps the $\mathrm{Pb}$ content of LMR suspended sediments has remained relatively constant since the early- to mid-2000s. Moreover, the $\mathrm{Cu}$ content, along with the $\mathrm{Pb}$ data discussed above, is further evidence that these metals are largely transported on small, suspended particulate matter or colloids in the LMR. Nevertheless, because Trefry and co-workers employed $0.4 \mu \mathrm{m}$ pore-size filters to collect suspended sediments from the Mississippi River, definitive conclusions regarding the possibility that $\mathrm{Pb}$ (and Cu) contents of LMR suspended sediments have increased since the 1980s and 1990s, or remained constant since the early 2000s, will require more sampling.

Although the MRSS sample analyzed in this contribution is insufficient to establish whether particulate $\mathrm{Pb}$ loads in the Mississippi River have increased since the late 20th century, it is interesting to speculate as to what processes could lead to increases in $\mathrm{Pb}$ contents. We suggest that the most likely cause could be increasing urbanization within the watershed along with increasing runoff of urban soils/sediments with a legacy of atmospheric $\mathrm{Pb}$ deposition [45,94-98]. Moreover, urban runoff is expected to increase as more land is converted to impermeable surfaces (e.g., roads and parking lot paving, etc.). Resuspension and transport of $\mathrm{Pb}$ contaminated urban soils and sediments could have also increased as a result of more intense precipitation events driven by changes in climate. Such processes may also increase loading of other metals commonly attributed to urban land use such as cadmium $(\mathrm{Cd}), \mathrm{Co}$, chromium $(\mathrm{Cr}), \mathrm{Cu}$, molybdenum $(\mathrm{Mo})$, vanadium $(\mathrm{V})$, and $\mathrm{Zn}$ to rivers such as the Mississippi and its tributaries $[95,96]$, which may also explain the increases in $\mathrm{Cu}$ contents we observe. Another possibility that might explain higher $\mathrm{Pb}$ and $\mathrm{Cu}$ contents could be corrosion of water distribution systems (e.g., pipes, valves, waste-water treatment facility infrastructure) owing to increasing chloride concentrations from road salts, drinking water disinfection treatments, and other industrial and urban sources (e.g., [99]).

Comparison of the trace element contents we measured in the modern riverbank sediments (MRBS) to the average of 30 sediment samples from the Mississippi Delta analyzed by Trefry and Presley [38] reveals that the modern riverbank sediments exhibit 2.8-fold lower $\mathrm{Pb}$, 3.4-fold lower $\mathrm{Zn}$, 2 -fold lower $\mathrm{Co}$ and Ni contents, but nearly the same $\mathrm{Cu}$ contents (Tables 2 and 4). As suggested by Trefry and co-workers the generally lower metal contents of the modern riverbank sedimentary 
deposits compared to these delta sediments and our modern suspended sediment sample probably reflects remobilization of the metals as environmental conditions change during deposition and early diagenesis (e.g., reductive dissolution of Fe/Mn oxides/oxyhydroxides, oxidation of organic matter) compared to the conditions within the oxic river waters $[36,37,64,91,100]$.

On average the pre-industrial deltaic deposits obtained from the borehole (i.e., TU 169, TU 171) have $\mathrm{Pb}$ and $\mathrm{Co}$ contents that are between two and three times lower than the values reported by Swarzenski et al. [92] for pre-industrial sediments collected offshore, and 6-fold lower $\mathrm{Cu}$ contents than these offshore sediments (Tables 2 and 4). It is noteworthy that our pre-industrial samples represent older natural deposits than those of Swarzenski et al. [92] and are obtained from a different depositional environment (see [75]). Because our pre-industrial samples were deposited by past pathways of the Mississippi River and comprised the Late-Holocene LMR delta plain, they are a better analogue for comparison with modern river sedimentary deposits and suspended sediments than the pre-industrial samples collected offshore by others. This is because the source of offshore sediments is uncertain; it may include river input or longshore transport from elsewhere, and river sediment input may have experienced mixing with marine sediments or reworking by waves, tides, and storms in the offshore environment.

\subsection{Fate of LMR Sediment-Associated Metals in New Coastal Marshlands}

Our results are consistent with the studies of Trefry and co-workers who also found that trace metals like $\mathrm{Fe}, \mathrm{Mn}, \mathrm{Pb}, \mathrm{Zn}, \mathrm{Cd}, \mathrm{Cu}$, and $\mathrm{Ni}$ were primarily associated with environmentally labile fractions of LMR suspended sediments [36-38,91]. Furthermore, Reiman et al. [101] showed that there is a significant correlation between total suspended solids and metal concentrations (i.e., $\mathrm{Al}, \mathrm{Ba}, \mathrm{Fe}, \mathrm{Mn}$, $\mathrm{P}, \mathrm{K}, \mathrm{Si}, \mathrm{Tl}$, and $\mathrm{V}$ ) in the Mississippi River system, which also indicates that suspended sediments are an important reservoir and mechanism of metal transport in the river. These studies, along with our analyses, clearly demonstrate that substantial portions of the metal load within the Mississippi River are transported as environmentally labile fractions within the suspended sediments that are likely to be bioavailable if conditions change following deposition of these materials (see Tables 2 and 4).

Although the readily exchangeable and acid leachable fractions (i.e., Fractions 1 and 2) account for a small percentage of the total metal contents of the LMR sediments we analyzed, our results also show that the percentage of metals that could be mobilized from suspended sediment (i.e., MRSS sample) upon deposition within a coastal marsh setting where anaerobic conditions will predominate is potentially quite high (see Figure 2). Specifically, the highest contents of environmentally labile, and hence, bioavailable fractions of the trace elements we analyzed (i.e., $\mathrm{Cu}, \mathrm{Co}, \mathrm{Ni}, \mathrm{Pb}$, and $\mathrm{Zn}$ ) in the LMR sediments sample occur in the reducible fraction (i.e., Fraction 3) of the MRSS sample (Tables 2 and 3). The metal contents of the reducible fraction of the MRSS sample shows that as much as $64 \%$ of the total $\mathrm{Pb}(31.3 \mathrm{mg} / \mathrm{kg}), 33 \%$ of the total $\mathrm{Zn}(33.4 \mathrm{mg} / \mathrm{kg}), 49 \%$ of the total Co $(6.11 \mathrm{mg} / \mathrm{kg}), 18 \%$ of the total Ni $(5.84 \mathrm{mg} / \mathrm{kg})$, and $31 \%$ of the total $\mathrm{Cu}(24.3 \mathrm{mg} / \mathrm{kg})$ carried by LMR suspended sediments is associated with reducible $\mathrm{Fe}(\mathrm{III}) / \mathrm{Mn}(\mathrm{IV})$ oxides/oxyhydroxides (Figures 2 and $\mathrm{A} 1$ ). We note that these $\mathrm{Pb}, \mathrm{Cu}$, and $\mathrm{Co}$ distributions are consistent with results from past studies that showed the Mississippi River suspended and bank sediments are enriched in $\mathrm{Pb}$ and other metals that are mostly adsorbed onto $\mathrm{Fe}(\mathrm{III}) / \mathrm{Mn}(\mathrm{IV})$ oxides/oxyhydroxides, and to a lesser extent clay minerals and organic matter [33,34,54,91]. Moreover, Shiller [102] showed that $\mathrm{Pb}$ (as well as $\mathrm{Zn}$ ) is strongly adsorbed onto Mn and Fe oxides in Mississippi River sediments and Stolpe et al. [103] presented evidence of $\mathrm{Pb}$ transport in the water column by Fe-rich colloidal matter exceeding $40 \mathrm{~nm}$ in size. Consequently, an important finding of this, and these earlier studies, is that substantial amounts of $\mathrm{Pb}, \mathrm{Co}, \mathrm{Zn}$, and $\mathrm{Cu}$ could be potentially mobilized from LMR suspended sediments by reductive dissolution of the $\mathrm{Fe}(\mathrm{III}) / \mathrm{Mn}(\mathrm{IV})$ oxide/oxyhydroxide mineral-grain coatings and/or colloids associated with these sediments upon their deposition within the planned Mid-Barataria Bay and Mid-Breton Sound diversions to build new marshlands (Figures 1 and A1; Tables 2 and 3 and Table A1 ). 
Table 4. Summary of trace metal content (in $\mathrm{mg} / \mathrm{kg}$ ) data for sediments from the Lower Mississippi River (LMR). Suspended sediment samples are labeled as SS.

\begin{tabular}{|c|c|c|c|c|c|c|c|c|c|c|c|}
\hline & $\begin{array}{c}\text { SS } \\
(1973)^{a}\end{array}$ & $\begin{array}{c}\text { SS } \\
(1974)^{b}\end{array}$ & $\begin{array}{c}\text { SS } \\
(1982)^{c}\end{array}$ & $\begin{array}{c}\text { SS } \\
(1991)^{d}\end{array}$ & SS-BCLA ${ }^{\mathrm{e}}$ & $\begin{array}{l}\text { Colloids- } \\
\text { BCLA }^{\mathrm{f}}\end{array}$ & $\begin{array}{c}\text { SS-North } \\
\text { America Rivers } \mathrm{g}\end{array}$ & $\begin{array}{l}\text { SS-Ave. World } \\
\text { Rivers } \mathrm{g}\end{array}$ & $\begin{array}{c}\text { Delta } \\
\text { Sediments }\end{array}$ & $\begin{array}{l}\text { Pre-Industrial } \\
\text { Metals }^{i}\end{array}$ & Upper Crust $\mathrm{g}$ \\
\hline $\mathrm{Pb}$ & 45.5 & 46 & & & $30.3 \pm 3.1$ & 38,49 & 22 & 61.1 & 35.1 & 15.1 & 132 \\
\hline $\mathrm{Zn}$ & 184 & 193 & & & $160 \pm 27.5$ & 183,212 & 137 & 208 & 160 & & 134 \\
\hline Co & 21.2 & 21 & $32 \pm 3$ & $27-34$ & & & 15 & 22.5 & 18.9 & 11.4 & 20 \\
\hline $\mathrm{Ni}$ & 55.6 & 55 & & & & & 50 & 74.5 & 39.3 & & 20 \\
\hline $\mathrm{Cu}$ & 42.3 & 45 & & & $50.7 \pm 5.9$ & 62,72 & 34 & 75.9 & 29.2 & 24.2 & 25 \\
\hline
\end{tabular}

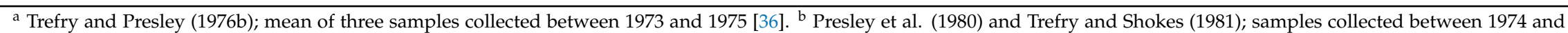

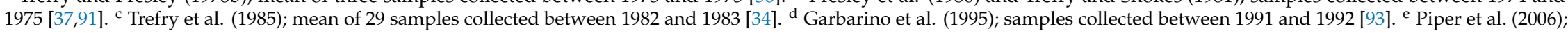
mean of three samples of size fraction $>1 \mathrm{~mm}$ referred to as "suspended silt" by the authors. BCLA refers to Belle Chase, LA, located $117 \mathrm{~km}$ upriver from Head of Passes [64]. ${ }^{\mathrm{f}}$ Piper et al. (2006); two samples of size fraction $>1 \mathrm{~mm}$ referred to as "colloidal" by the authors [64]. ${ }^{\mathrm{g}}$ Viers et al. (2009); an average of 21 major rivers from North America and the major world rivers [100]. ${ }^{\mathrm{h}}$ Trefry and Presley (1976a); mean of 30 sediment samples collected from the Mississippi River delta [38]. ${ }^{1}$ Swarzenski et al. (2006); an average of six samples from a long sediment core dated to greater than 800 years in age [92]. 
In addition to the amounts of trace metals associated with $\mathrm{Fe}(\mathrm{III}) / \mathrm{Mn}(\mathrm{IV})$ oxides/oxyhydroxides, approximately $12 \%$ and $17 \%$ of the total $\mathrm{Pb}$ and $\mathrm{Cu}$ contents (i.e., $5.77 \mathrm{mg} / \mathrm{kg}$ and $13.2 \mathrm{mg} / \mathrm{kg}$, respectively) are associated with the oxidizable fraction (i.e., Fraction 4) within the MRSS sample (Figure A1, Table A1). Lower amounts of the total Zn, Co, and Ni contents of the LMR suspended sediments (i.e., around 7\% of each) are associated with the oxidizable fraction (Table A1). The oxidizable fraction of the sediments likely reflects particulate organic matter or terrestrial-sourced fulvic acid colloids previously identified within the Mississippi River water [103]. Such colloids would likely collect on $0.4 \mu \mathrm{m}$ filters as larger suspended matter begins to clog the pores. Organic colloidal materials could also be adsorbed onto the suspended mineral sediments and thus be carried along with the larger particulate matter within the flowing river waters (e.g., [104-109]). Similar to the case for trace metals associated with the reducible $\mathrm{Fe} / \mathrm{Mn}$ oxide/oxyhydroxide fraction discussed above, trace metals associated with the oxidizable organic matter fraction of the LMR suspended sediments could also be mobilized by microbial degradation of the organic matter once deposited within the anaerobic coastal marsh systems, such as those planned for Mid-Barataria Bay and Mid-Breton Sound (Figure 1). It is unlikely that the oxidizable fraction of Mississippi River suspended sediments represents metal sulfide minerals as these would be oxidized during weathering at their source, and furthermore, are likely to be too dense to be transported with suspended sediments in the river waters.

Taken together, the burial of suspended sediments from the LMR within the proposed Mid-Barataria Bay and Mid-Brenton Sound diversions [21,22] could potentially mobilize as much as $76-84 \%$ of the total $\mathrm{Pb}$ content (i.e., $37.1-40.8 \mathrm{mg} / \mathrm{kg}$ ) carried by these suspended sediments into pore waters of the newly constructed marshes. Lead $(\mathrm{Pb})$ mobilization will occur as the in situ burial conditions become progressively more reducing owing to anaerobic respiration of organic carbon where microbes utilize terminal electron acceptors like nitrate ions carried by the river waters, $\mathrm{Fe}(\mathrm{III}) / \mathrm{Mn}(\mathrm{IV})$ oxides/oxyhydroxide coatings on the suspended sediment grains (Fraction 3), and dissolved sulfate ions from marine sources, among others. These same early diagenetic changes of in situ conditions could also mobilize as much as $40-47 \%$ of the total $\mathrm{Zn}(40.4-47.2 \mathrm{mg} / \mathrm{kg}), 57-59 \%$ of the total Co $(7-7.33 \mathrm{mg} / \mathrm{kg}), 22-26 \%$ of the total Ni $(8.3-8.9 \mathrm{mg} / \mathrm{kg})$, and $48-51 \%$ of the total $\mathrm{Cu}(37.5-43.5 \mathrm{mg} / \mathrm{kg})$ carried by the LMR suspended sediments (Tables 2 and A1). The impacts of these mobilized metals on the marshland biota could be detrimental to these organisms as well as those occupying higher trophic levels (e.g., humans) as many metals including $\mathrm{Pb}, \mathrm{Cu}$, and $\mathrm{Ni}$ are known to bioaccumulate within the food chain [110-115].

The generally higher metal contents in the LMR suspended sediments compared to the modern riverbank deposits (i.e., MRBS) may indicate that microbial reduction of $\mathrm{Fe}(\mathrm{III}) / \mathrm{Mn}$ (IV) oxides/oxyhydroxides has occurred within these sediments. Here, microbial respiration may have been fueled by labile dissolved organic carbon (DOC) from the Mississippi River or organic matter associated with the sediments (e.g., Fraction 4). Such a process would mobilize $\mathrm{Pb}$ and the other trace elements associated with the reducible and oxidizable fractions of the sediments deposited on the modern riverbank. This notion is consistent with the more than 7 -fold lower $\mathrm{Pb}$ content of the reducible fraction of the modern riverbank sedimentary deposits (MRBS) compared to the Pb content of the same fraction of the suspended sediment sample (MRSS; Table 2). Perhaps more remarkable is that the $\mathrm{Cu}$ content of the reducible fraction of MRBS is 20 times lower than in the same fraction of the LMR suspended sediment sample (Table 2). Similar observations were reported by Davranche et al. [116] in their investigation of trace metal behavior in sediments from Mortagne-du-Nord, France under reducing conditions that showed no trace metal mobilization from younger sulfide-laden sediments but an increase in trace metal contents in older oxidized, organic-rich sediments. These authors attributed these trace metal distributions to their mobilization from the sediments by reductive dissolution of $\mathrm{Fe}$ oxides/oxyhydroxides. 
The amount of each trace element associated with the reducible fraction in the pre-industrial deltaic deposits is even lower. For example, compared to the LMR suspended sediment sample, the $\mathrm{Pb}$ content of the reducible fractions of the pre-industrial deltaic deposits is on average 70-fold lower than in the reducible fraction of the MRSS sample, and the $\mathrm{Cu}$ content is 134 times lower in the same fraction of pre-industrial deposits compared to MRSS (Table 2). Although the much lower trace metal contents of the reducible fraction of the pre-industrial deltaic deposits may reflect, at least in part, post-depositional remobilization of the trace metals by reductive dissolution of $\mathrm{Fe}(\mathrm{III}) / \mathrm{Mn}(\mathrm{IV})$ oxides/oxyhydroxides, we contend that the very low trace metal contents of these sediments also reflect the pre-anthropogenic lack of contaminant and heavy metal input by industry, agriculture, and infrastructure to support burgeoning populations, that characterize the post-industrial river catchment and corridor in present-day southern Louisiana.

\subsection{Estimating Pore Water Trace Metal Concentrations in Newly Constructed Marshlands}

The cumulative $\mathrm{Pb}$ contents in the modern LMR suspended sediment (i.e., MRSS) gives insight into the magnitude of potential trace metal contamination to marshland pore waters following the diversion of these materials into the planned Mid-Barataria Bay and Mid-Breton Sound receiving basins (Figure 1). We assume that the natural, background $\mathrm{Pb}$ content for Mississippi River sediments is roughly equal to the $\mathrm{Pb}$ content of the pre-industrial deltaic deposits (TU 169 and TU 171; ca. $5.9 \mathrm{mg} / \mathrm{kg}$ ). Again, the low metal contents in conjunction with the intact luminescence signals and overlying deltaic strata [75] strongly suggest that modern-day events or disturbances have not impacted these sediments, and thus they likely reflect the historical background $\mathrm{Pb}$ concentrations in the Mississippi River before industrialization in the early 1800s [91]. Therefore, a comparison of $\mathrm{Pb}$ contents in the reducible fraction of the pre-industrial deltaic deposits (ranging from 0.42 to $0.48 \mathrm{mg} / \mathrm{kg}$; mean = ca. $0.45 \mathrm{mg} / \mathrm{kg}$ ) with the same fraction of modern Mississippi river suspended sediments $(31.3 \mathrm{mg} / \mathrm{kg}$ ) and modern bank deposits $(4.26 \mathrm{mg} / \mathrm{kg})$, suggests that present-day sediments include a sizeable component of anthropogenic $\mathrm{Pb}$ (i.e., future $\mathrm{Pb}$ isotope studies are planned to verify this supposition). Furthermore, the high $\mathrm{Pb}$ concentrations measured in the reducible fraction of the MRSS (i.e., ca. $64 \%$ of the total $\mathrm{Pb}$ content; Table A1) indicates that the suspended sediments are the chief reservoir for bioavailable $\mathrm{Pb}$, which implies that diagenetic processes that result in the reduction of $\mathrm{Fe} / \mathrm{Mn}$ oxides/oxyhydroxides will mobilize $\mathrm{Pb}$ during initial-deposition or post-deposition into the associated pore waters (see Figure 2; Table 2).

Following the approach of Hering and Kneebone [117], we estimate the concentration of $\mathrm{Pb}$ that could be released to pore waters in the planned marshes of the Mid-Barataria Bay and Mid-Breton Sound diversions assuming that LMR suspended sediments of the same composition as the MRSS sample analyzed herein are deposited in these planned diversion sites. Using the expression from Hering and Kneebone [117] modified for $\mathrm{Pb}$, we have:

$$
f=\frac{[\mathrm{Pb}]_{\mathrm{diss}} \times \varnothing}{\mathrm{M} \times \mathrm{D} \times(1-\varnothing) \times 1000}
$$

in which, $f$ is the fraction of sediment bounded $\mathrm{Pb}$ released to support a dissolved $\mathrm{Pb}$ concentration in the pore waters, $[\mathrm{Pb}]_{\text {diss }}$ is the dissolved $\mathrm{Pb}$ concentration in $\mu \mathrm{g} / \mathrm{kg}$ mobilized from the sediments, $\mathrm{M}$ is total $\mathrm{Pb}$ content (i.e., $\mathrm{Pb}_{\text {total }}$ ) of the diverted sediment in $\mathrm{mg} / \mathrm{kg}, \mathrm{D}_{\text {sed }}$ is the specific gravity of the sediment grains, and $\varnothing$ is the porosity of the sediments (see also [118]). For the MRSS sediment, the total Pb content, M, of MRSS is $50.9 \mathrm{mg} / \mathrm{kg}$ (Table 2). Piper et al. [64] report that approximately $25 \%$ of the suspended clastic sediments carried by the Mississippi River consist of quartz, which has a specific gravity of $2.65 \mathrm{~g} / \mathrm{cm}^{3}$. If we assume that the remaining $75 \%$ consists of clay minerals, for which the specific gravity is ca. $2.78 \mathrm{~g} / \mathrm{cm}^{3}$ (i.e., mean value from [119]), we compute a weighted average for the specific gravity of LMR suspended sediments of $2.76 \mathrm{~g} / \mathrm{cm}^{3}$. We employ an average porosity for the LMR marshland sediments of $89 \pm 3 \%$, determined by Breaux [79] and Telfeyan et al. [67]. Imputing these values into Equation (1), and assuming that only the reducible fraction (i.e., Fraction 3 
or $64.2 \%$ of $\mathrm{Pb}_{\text {total }}$ or $31.3 \mathrm{mg} / \mathrm{kg}$; Tables 2 and A1) of the MRSS is mobilized within the newly formed marshlands, we estimate a dissolved $\mathrm{Pb}$ concentration in the pore waters of ca. $11 \mathrm{mg} / \mathrm{kg}$ could occur. By comparison, the U.S. EPA "action level" for Pb in drinking water is $0.015 \mathrm{mg} / \mathrm{L}$ (i.e., $\mathrm{mg} / \mathrm{kg}$; [120]). This "action level" is more than 700-fold lower than our estimate of the potential pore water $\mathrm{Pb}$ concentrations within the planned Mid-Barataria Bay and Mid-Breton Sound diversions if only $\mathrm{Fe}(\mathrm{III}) / \mathrm{Mn}(\mathrm{IV})$ oxides/oxyhydroxides associated with the LMR suspended sediments are dissolved. If all of the environmentally labile $\mathrm{Pb}$ were mobilized (i.e., Fractions 1-4), we estimate a potential pore water $\mathrm{Pb}$ concentration as high as $14.5 \mathrm{mg} / \mathrm{kg}$. Identical calculations for $\mathrm{Cu}$ suggest a pore water $\mathrm{Cu}$ concentration of $8.27 \mathrm{mg} / \mathrm{kg}$ if only the $\mathrm{Cu}$ associated with $\mathrm{Fe}(\mathrm{III}) / \mathrm{Mn}(\mathrm{IV})$ oxides/oxyhydroxides in the MRSS is mobilized in the newly constructed marshes, and as much as $14.9 \mathrm{mg} / \mathrm{kg}$ if all of the environmentally labile $\mathrm{Cu}$ were mobilized. The "action level" for $\mathrm{Cu}$ is $1.3 \mathrm{mg} / \mathrm{L}$ (i.e., $\mathrm{mg} / \mathrm{kg}$; [120]). These simple calculations indicate that substantial amounts of environmentally labile (i.e., bioavailable) $\mathrm{Pb}$ and $\mathrm{Cu}$ in the MRSS could be mobilized at potentially ecologically concerning concentrations into pore waters of the planned coastal marshlands after diversion of river sediments into these receiving basins. The impact of these mobilized trace metals on marshland flora and fauna, and perhaps more critically, on the local seafood industry and human health warrant careful study and consideration.

\section{Conclusions}

We investigated the potential impact of CPRA's proposed Mid-Barataria Bay and Mid-Breton Sound diversion projects on marshland pore water quality by focusing on sediments from the Lower Mississippi River (LMR), which represent the chief material envisioned for building new marshlands in these planned diversions. Suspended sediments from the modern river, modern riverbank sedimentary deposits, and two pre-industrial samples of Late-Holocene-aged deltaic sedimentary deposits were collected and analyzed for the $\mathrm{Co}, \mathrm{Cu}, \mathrm{Ni}, \mathrm{Pb}$, and $\mathrm{Zn}$ contents. We also subjected these sediments to sequential extraction analysis to evaluate the speciation of these trace elements in these LMR sediments. The sequential extraction analysis provides a means for determining the environmentally labile fraction of these trace metals that may be bioavailable to marshland organisms. Although the majority of all of these metals typically occur within the non-labile, alumino-silicate minerals that make up the bulk of these sediments, in most cases, the environmentally labile trace metals are chiefly associated with the chemically reducible fractions of these sediments. This reducible fraction likely represents $\mathrm{Fe}(\mathrm{III}) / \mathrm{Mn}(\mathrm{IV})$ oxides/oxyhydroxides that occur as coatings on mineral grains from oxic environments like the Mississippi River. The other important environmentally labile pool of trace metals in the sediments are those associated with oxidizable materials like organic matter. The fate and transport of these metals will depend on the biogeochemical processes occurring in the marshlands after suspended sediment diversion. Such processes may include reductive dissolution Fe-Mn oxyhydroxides, mobilization of associated metals to the water column, re-adsorption, complexation with dissolved organic ligands, microbially mediated reduction of organic matter, and/or metal uptake and intracellular reduction by native aquatic biota. Thus, trace metals associated with the reducible fraction and oxidizable fraction of these sediments are expected to be mobilized in the new marshlands planned for the Mid-Barataria Bay and Mid-Breton Sound diversions as the pore water, and sediment condition becomes progressively anaerobic as a result of early diagenetic processes and organic matter degradation.

According to the EPA's water quality criteria for suspended and bedded sediments [121], quality and quantity of aquatic sediments can impair water bodies and alter the behavior, health, or ultimate survival of biota. The LMR diversion projects may mobilize potentially toxic metals like $\mathrm{Pb}$ and $\mathrm{Cu}$ from the diverted, buried, re-suspended, or re-deposited sediments into the pore water. These mobilized metals can be transferred into the aquatic food chain and accumulate into the tissues of aquatic biota (such as fish, crustaceans, and bivalve species), which is eventually consumed by humans especially given the popularity of the seafood industry in southern Louisiana [122-124]. There is a human health risk involved with ingesting metals (especially $\mathrm{Pb}$ which bioaccumulates) from fish and 
other aquatic species. Therefore, further research should be conducted on the dual impact that the diversion projects have on the geochemistry and aquatic species in this marshland ecosystem.

Author Contributions: Conceptualization, K.H.J.; methodology, O.A.A., S.A.A. and A.S.T.; validation, K.H.J.; formal analysis, O.A.A.; resources, K.H.J.; writing—original draft preparation, O.A.A., A.S.T., S.A.A., and K.H.J.; writing-review and editing, O.A.A., A.S.T., E.C., S.A.A., and K.H.J.; supervision, K.H.J.; funding acquisition, K.H.J. All authors have read and agreed to the published version of the manuscript.

Funding: This research received no external funding.

Acknowledgments: This research was primarily supported by funds provided to the Department of Earth and Environmental Sciences at Tulane University by Michael and Mathilda Cochran, who established the Cochran Family Professorship. Karen Johannesson is especially grateful to Michael and Mathilda Cochran and the Cochran family in general for making this important gift to Tulane University, which dramatically impacted her research productivity since 2015. Omolola Akintomide would also like to thank the Department of Earth and Environmental Sciences at Tulane University for providing additional funds via graduate assistantships that supported her Ph.D. education. We are very grateful to Mead Allison and his research team for their assistance with the MRSS samples and information about our study area and Deborah Grimm for assistance with the ICP-MS analysis.

Conflicts of Interest: The authors declare no conflict of interest. The authors have no known competing financial interests or personal relationships that could have appeared to influence the work reported in this paper.

\section{Appendix A}

Table A1. Percentage distribution of metals in their "operationally defined solid-phase" fractions. Shown are the percentage concentrations \pm the analytical error of each analysis.

\begin{tabular}{|c|c|c|c|c|c|c|}
\hline Metal & Sample No. & $\begin{array}{c}\text { Fraction } 1 \\
(\%)\end{array}$ & $\begin{array}{c}\text { Fraction } 2 \\
(\%)\end{array}$ & $\begin{array}{c}\text { Fraction } 3 \\
(\%)\end{array}$ & $\begin{array}{c}\text { Fraction } 4 \\
(\%)\end{array}$ & $\begin{array}{c}\text { Fraction } 5 \\
(\%)\end{array}$ \\
\hline \multirow{4}{*}{$\mathrm{Pb}$} & TU 171 & $0.12^{\mathrm{a}}$ & $2.23^{a}$ & $8.77 \pm 2.63$ & $14.0^{\mathrm{a}}$ & $74.9 \pm 3.00$ \\
\hline & TU 169 & $\mathrm{~b}$ & $2.70 \pm 0.08$ & $6.73 \pm 0.29$ & $8.19 \pm 0.81$ & $82.4 \pm 3.21$ \\
\hline & MRSS & $0.06^{\mathrm{a}}$ & $7.64 \pm 0.21$ & $64.2 \pm 1.09$ & $11.9 \pm 0.34$ & $16.3 \pm 1.40$ \\
\hline & MRBS & $0.02^{a}$ & $7.72 \pm 0.65$ & $33.2 \pm 0.22$ & $9.34^{\mathrm{a}}$ & $49.7 \pm 0.38$ \\
\hline \multirow{4}{*}{$\mathrm{Zn}$} & TU 171 & $0.24^{\mathrm{a}}$ & $2.74 \pm 0.06$ & $5.21 \pm 0.33$ & $14.4 \pm 1.44$ & $77.5 \pm 3.49$ \\
\hline & TU 169 & $0.15^{\mathrm{a}}$ & $1.48 \pm 0.13$ & $6.53 \pm 0.59$ & $16.1 \pm 1.22$ & $75.8 \pm 2.05$ \\
\hline & MRSS & $1.79 \pm 0.01$ & $5.05 \pm 0.18$ & $33.4 \pm 0.73$ & $6.97 \pm 0.21$ & $52.8 \pm 1.16$ \\
\hline & MRBS & $\mathrm{b}$ & $3.62 \pm 0.09$ & $22.8 \pm 0.23$ & $5.75 \pm 0.23$ & $67.1 \pm 0.47$ \\
\hline \multirow{4}{*}{ Co } & TU 171 & $0.69^{a}$ & $3.96^{\mathrm{a}}$ & $9.09 \pm 0.51$ & $23.7 \pm 0.52$ & $62.7 \pm 1.45$ \\
\hline & TU 169 & $0.57^{\mathrm{a}}$ & $3.03 \pm 0.34$ & $11.3 \pm 0.69$ & $23.0 \pm 2.17$ & $62.1 \pm 2.48$ \\
\hline & MRSS & $0.13^{a}$ & $2.25^{\mathrm{a}}$ & $49.4 \pm 1.82$ & $7.38 \pm 0.21$ & $40.8 \pm 1.95$ \\
\hline & MRBS & $0.03^{a}$ & $0.33^{a}$ & $42.5 \pm 0.85$ & $11.8 \pm 0.21$ & $45.3 \pm 1.27$ \\
\hline \multirow{4}{*}{$\mathrm{Ni}$} & TU 171 & $0.24^{\mathrm{a}}$ & $2.36^{\mathrm{a}}$ & $9.27 \pm 0.56$ & $24.0 \pm 0.84$ & $64.1 \pm 2.24$ \\
\hline & TU 169 & $0.20^{a}$ & $2.12 \pm 0.08$ & $9.7 \pm 0.46$ & $23.1 \pm 1.70$ & $64.9 \pm 1.16$ \\
\hline & MRSS & $0.48^{a}$ & $1.33 \pm 0.07$ & $17.7 \pm 0.42$ & $7.43 \pm 0.25$ & $73.1 \pm 1.02$ \\
\hline & MRBS & $\mathrm{b}$ & $0.76^{\mathrm{a}}$ & $22.4 \pm 0.54$ & $10.3 \pm 0.27$ & $66.5 \pm 2.26$ \\
\hline \multirow{4}{*}{$\mathrm{Cu}$} & TU 171 & $0.59^{a}$ & $3.27^{\mathrm{a}}$ & $3.68^{a}$ & $20.1 \pm 1.09$ & $66.3 \pm 3.11$ \\
\hline & TU 169 & $0.43^{\mathrm{a}}$ & $2.88 \pm 0.39$ & $5.07 \pm 0.39$ & $19.7 \pm 0.81$ & $69.0 \pm 4.62$ \\
\hline & MRSS & $0.70 \pm 0.02$ & $6.90 \pm 0.13$ & $30.7 \pm 0.44$ & $16.8 \pm 0.17$ & $42.9 \pm 1.97$ \\
\hline & MRBS & $0.18^{\mathrm{a}}$ & $0.99 \pm 0.03$ & $3.69 \pm 0.05$ & $9.40 \pm 0.23$ & $85.7 \pm 1.88$ \\
\hline
\end{tabular}

${ }^{a}$ Percentage concentrations lacking an associated error indicate that the analytical errors for these analyses were less than $\pm 0.01 \% .{ }^{b}$ Below detection limit. 

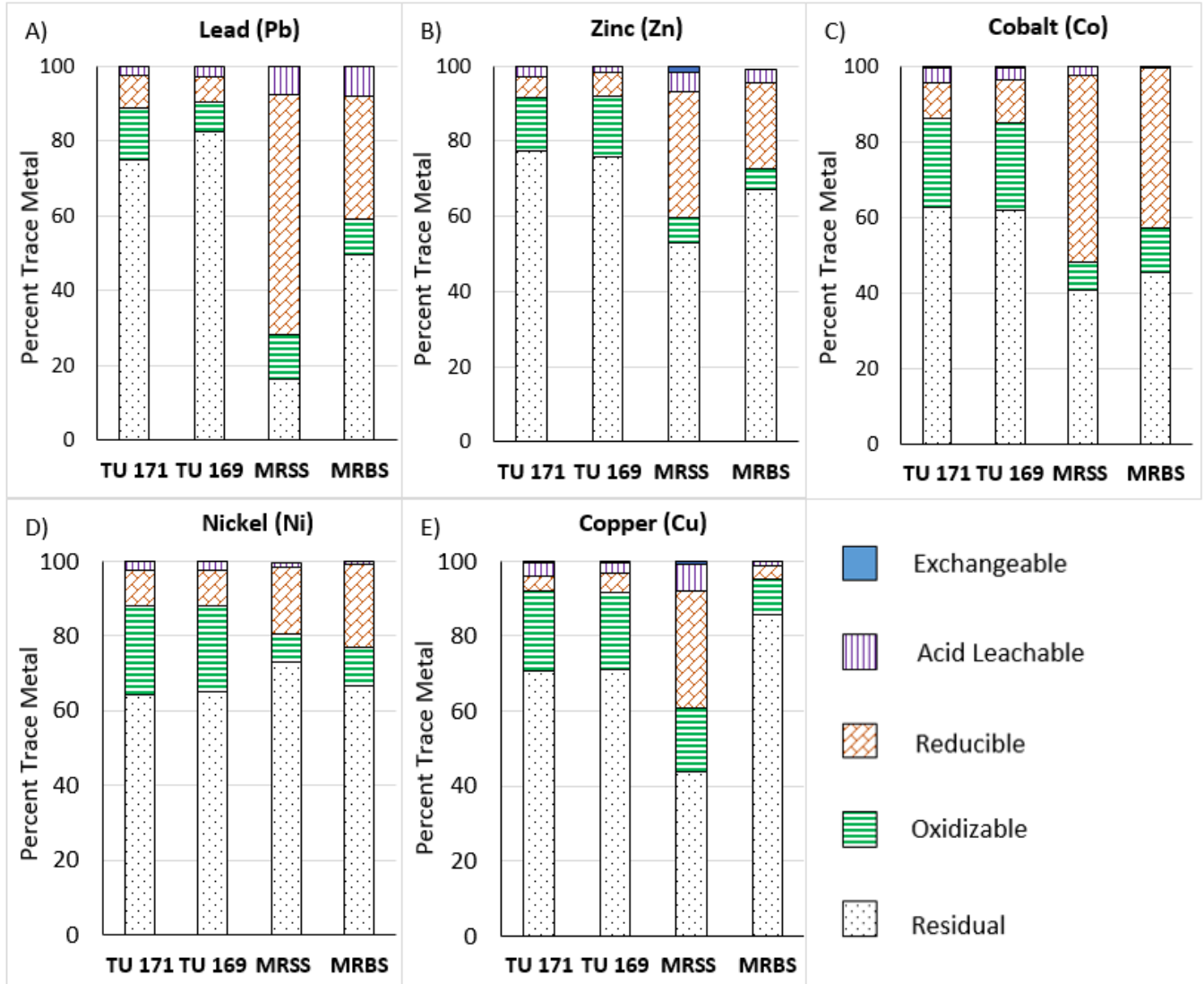

|InIf Acid Leachable

Reducible

Oxidizable

Residual

Figure A1. Percentage distribution of metals in their "operationally defined solid-phase" fractions for pre-industrial deltaic deposits (TU 171 and TU 172), modern suspended sediments, and modern riverbank deposits of the Mississippi River. The percentages are calculated based on the absolute concentrations determined by the inductively coupled plasma mass spectrometry (ICP-MS) with detection limits of the extracted solution between $1 \mathrm{ng} / \mathrm{L}$ and $1 \mathrm{mg} / \mathrm{L}$ over the sum of all five fractions. Partitioning metals: (A) $\mathrm{Pb},(\mathbf{B}) \mathrm{Zn}(\mathbf{C}) \mathrm{Co},(\mathrm{D}) \mathrm{Ni}$, and (E) $\mathrm{Cu}$ in sediment into five phases. The exchangeable, acid leachable, reducible, oxidizable, and residual phases are based on the fractions that are affected by environmental conditions.

Table A2. The pre- and post-dissolution quantitative XRD result for the Mississippi River sediments.

\begin{tabular}{ccc}
\hline & (A) Pre-dissolution \\
\hline Mineral & 001 Peak Area & Relative Percent \\
\hline Quartz & 49,440 & 82.95441199 \\
Microcline & 7571 & 12.70323328 \\
Albite & 2588 & 4.342354737 \\
Mica/Clay & & Trace
\end{tabular}

\begin{tabular}{ccc}
\hline & (B) Post-dissolution \\
\hline Mineral & 001 Peak Area & Relative Percent \\
\hline Quartz & 39,595 & 77.12760777 \\
Microcline & 11,742 & 22.87239223 \\
Mica/clay & & Trace \\
\hline & 51,337 & \\
\hline
\end{tabular}



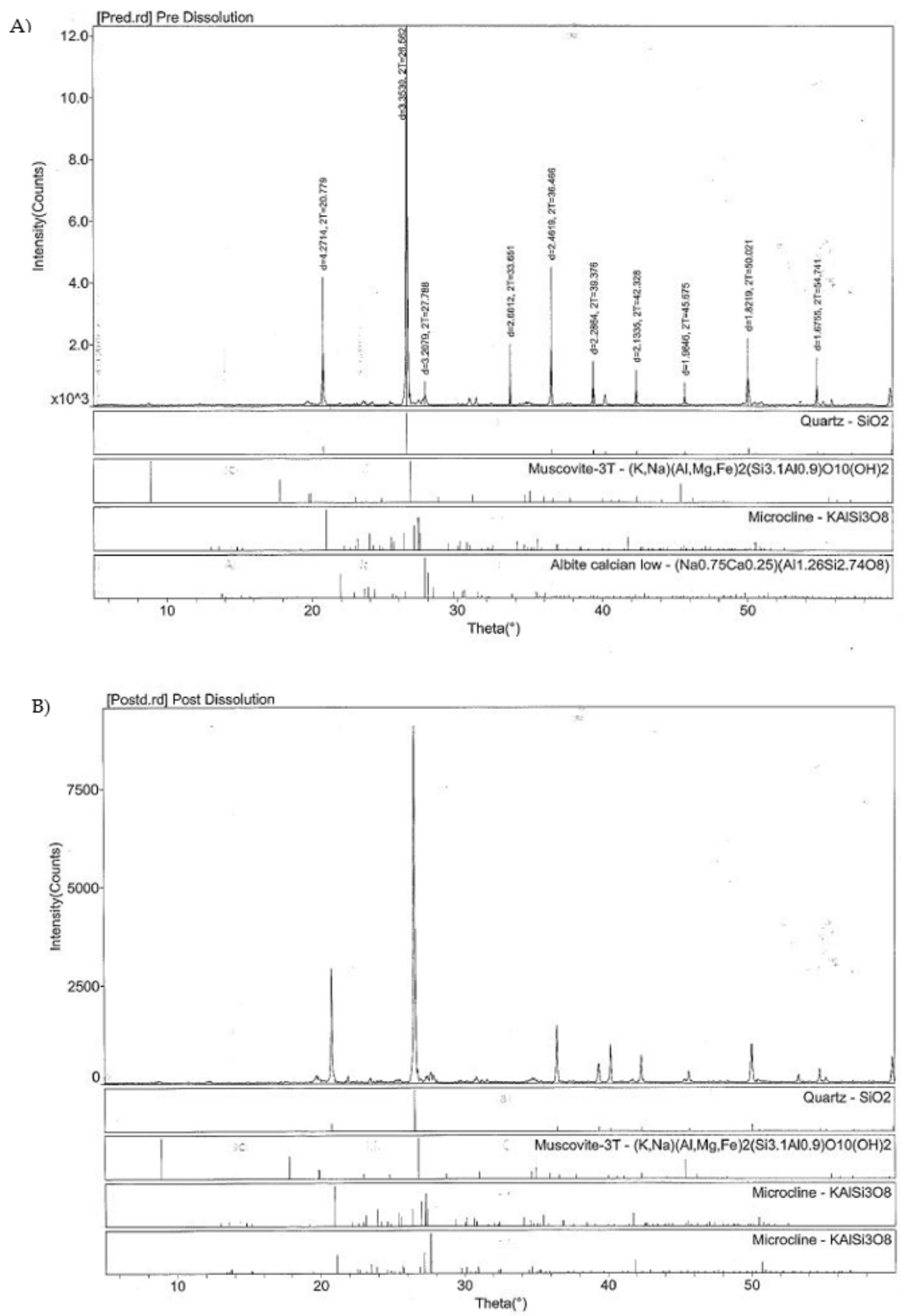

Figure A2. XRD results showing intensity and mineral relative percent for (A) pre-dissolution; and (B) post-dissolution of the Mississippi sediments. 


\section{References}

1. Day, J.W.; Templet, P.H. Consequences of sea level rise: Implications from the Mississippi delta. Coast. Manag. 1989, 17, 241-257. [CrossRef]

2. Stanley, D.J.; Warne, A.G. Nile Delta: Recent Geological Evolution and Human Impact. Science 1993, 260, 628-634. [CrossRef] [PubMed]

3. McInnes, K.L.; Walsh, K.J.E.; Hubbert, G.D.; Beer, T. Impact of Sea-level Rise and Storm Surges on a Coastal Community. Nat. Hazards 2003, 30, 187-207. [CrossRef]

4. Nicholls, R.J.; Lowe, J.A. Benefits of mitigation of climate change for coastal areas. Glob. Environ. Chang. 2004, 14, 229-244. [CrossRef]

5. Curtis, K.J.; Schneider, A. Understanding the demographic implications of climate change: Estimates of localized population predictions under future scenarios of sea-level rise. Popul. Environ. 2011, 33, $28-54$. [CrossRef]

6. Woodruff, J.D.; Irish, J.L.; Camargo, S.J. Coastal flooding by tropical cyclones and sea-level rise. Nature 2013, 504, 44-52. [CrossRef] [PubMed]

7. Giosan, L.; Syvitski, J.; Constantinescu, S.; Day, J.W. Climate change: Protect the world's deltas. Nature 2014, 516, 31-33. [CrossRef]

8. Nienhuis, P.H.; Leuven, R.S.E.W. River restoration and flood protection: Controversy or synergism. Hydrobiologia 2001, 444, 85-99. [CrossRef]

9. Day, J.W.; Barras, J.; Clairain, E.; Johnston, J.; Justic, D.; Kemp, G.P.; Ko, J.; Lane, R.; Mitsch, W.J.; Steyer, G.; et al. Implications of global climatic change and energy cost and availability for the restoration of the Mississippi delta. Ecol. Eng. 2005, 24, 253-265. [CrossRef]

10. Day, J.W.; Lane, R.R.; D’Elia, C.F.; Wiegman, A.R.H.; Rutherford, J.S.; Shaffer, G.P.; Brantley, C.G.; Kemp, G.P. Large Infrequently Operated River Diversions for Mississippi Delta Restoration. In Missississippi Delta Restoration; Estuaries of the World; Day, J., Erdman, J., Eds.; Springer: Cham, Switzerland; Berlin/Heidelberg, Germany, 2018; pp. 113-133. [CrossRef]

11. Bijker, W.E. American and Dutch coastal engineering: Differences in risk conception and differences in technological culture. Soc. Stud. Sci. 2007, 37, 143-151. [CrossRef]

12. Allison, M.A.; Meselhe, E.A. The use of large water and sediment diversions in the lower Mississippi River (Louisiana) for coastal restoration. J. Hydrol. 2010, 387, 346-360. [CrossRef]

13. Fabre, J.B. Sediment flux \& fate for a large-scale diversion: The 2011 Mississippi River Flood, the Bonnet Carré Spillway, and the Implications for coastal Restoration in South Louisiana. Master's Thesis, Louisiana State University and Agricultural and Mechanical College, LSU Digital Commons, Baton Rouge, LA, USA, 2012. Available online: https://pdfs.semanticscholar.org/9739/391e0d3863fb5f5db3586308412b5b3a94db.pdf (accessed on 26 May 2020).

14. Jonkman, S.N.; Hillen, M.M.; Nicholls, R.J.; Kanning, W.; van Ledden, M. Costs of Adapting Coastal Defences to Sea-Level Rise-New Estimates and Their Implications. J. Coast. Res. 2013, 29, 1212-1226. [CrossRef]

15. Temmerman, S.; Meire, P.; Bouma, T.J.; Herman, P.M.J.; Ysebaert, T.; De Vriend, H.J. Ecosystem-based coastal defence in the face of global change. Nature 2013, 504, 79-83. [CrossRef] [PubMed]

16. Stive, M.J.F.; De Schipper, M.A.; Luijendijk, A.P.; Aarninkhof, S.G.J.; Van Gelder-Maas, C.; Van Thiel de Vries, J.S.M.; De Vries, S.; Henriquez, M.; Marx, S.; Ranasinghe, R. A New Alternative to Saving Our Beaches from Sea-Level Rise: The Sand Engine. J. Coast. Res. 2013, 29, 1001-1008. [CrossRef]

17. Chan, F.; Huq, H.; Pinter, N.; Zegwaard, A. Trends in flood risk management in deltas around the world: Are we going 'soft'. Int. J. Water Gov. 2015, 3, 4.

18. Olea, R.A.; Coleman, J.L., Jr. A Synoptic Examination of Causes of Land Loss in Southern Louisiana as Related to the Exploitation of Subsurface Geologic Resources. J. Coast. Res. 2014, 30, 1025-1044. [CrossRef]

19. Törnqvist, T.E.; Jankowski, K.L.; Li, Y.; González, J.L. Tipping points of Mississippi Delta marshes due to accelerated sea-level rise. Sci. Adv. 2020, 6, eaaz5512. [CrossRef]

20. Chamberlain, E.L.; Törnqvist, T.E.; Shen, Z.; Mauz, B.; Wallinga, J. Anatomy of Mississippi Delta growth and its implications for coastal restoration. Sci. Adv. 2018, 4, eaar4740. [CrossRef]

21. CPRA. Coastal Restoration Authority of Louisiana. Louisiana's comprehensive master plan for a sustainable coast. Coast. Prot. Restor. Auth. Baton Rouge 2012, 188-190. Available online: http://www.coastalmasterplan. la.gov (accessed on 19 November 2019). 
22. CPRA. Coastal Restoration Authority of Louisiana. Louisiana's comprehensive master plan for a sustainable coast. Appendix B: People and The Landscape. 2017. Available online: http://coastal.la.gov/wp-content/ uploads/2017/04/Appendix-B_People-and-theLandscape_FINAL.pdf (accessed on 16 May 2020).

23. Rodning, C.B.; Mehta, J.M. Resilience and Persistent Places in the Mississippi River Delta of Southeastern Louisiana; Center for Archealogical Investigations. In Occassional Paper; SIU Press: Carbondale, IL, USA, $2015 ;$ p. 42.

24. Kolker, A.S.; Cable, J.E.; Johannesson, K.H.; Allison, M.A.; Inniss, L.V. Pathways and processes associated with the transport of groundwater in deltaic systems. J. Hydrol. 2013, 498, 319-334. [CrossRef]

25. Allison, M.A.; Demas, C.R.; Ebersole, B.A.; Kleiss, B.A.; Little, C.D.; Meselhe, E.A.; Powell, N.J.; Pratt, T.C.; Vosburg, B.M. A water and sediment budget for the lower Mississippi-Atchafalaya River in flood years 2008-2010: Implications for sediment discharge to the oceans and coastal restoration in Louisiana. J. Hydrol. 2012, 432-433, 84-97. [CrossRef]

26. Day, J.W.; Moerschbaecher, M.; Pimentel, D.; Hall, C.; Yáñez-Arancibia, A. Sustainability and place: How emerging mega-trends of the 21st century will affect humans and nature at the landscape level. Ecol. Eng. 2014, 65, 33-48. [CrossRef]

27. Amer, R.; Kolker, A.S.; Muscietta, A. Propensity for erosion and deposition in a deltaic wetland complex: Implications for river management and coastal restoration. Remote Sens. Environ. 2017, 199, 39-50. [CrossRef]

28. Xu, K.; Bentley, S.J.; Day, J.W.; Freeman, A.M. A review of sediment diversion in the Mississippi River Deltaic Plain. Estuar. Coast. Shelf Sci. 2019, 225, 106241. [CrossRef]

29. White, E.D.; Meselhe, E.; Reed, D.; Renfro, A.; Snider, N.P.; Wang, Y. Mitigating the Effects of Sea-Level Rise on Estuaries of the Mississippi Delta Plain Using River Diversions. Water 2019, 11, 2028. [CrossRef]

30. USACE. United States Army Corps of Engineers. Mid-Barataria Sediment Diversion Project: Final Scoping Report. USACE Website. 2018. Available online: https://www.mvn.usace.army.mil/Portals/56/docs/ regulatory/permits/EIS/2018_MBSD_Scoping\%20Report.pdf (accessed on 8 June 2020).

31. Cappuyns, V.; Swennen, R. Kinetics of element release during combined oxidation and pHstat leaching of anoxic river sediments. Appl. Geochem. 2005, 20, 1169-1179. [CrossRef]

32. Davidson, G.R.; Bennett, S.J.; Beard, W.C.; Waldo, P. Trace Elements in Sediments of an Aging Reservoir in Rural Mississippi: Potential for Mobilization Following Dredging. Water Air Soil Pollut. 2005, 163, 281-292. [CrossRef]

33. Miao, S.; De Laune, R.D.; Jugsujinda, A. Influence of sediment redox conditions on release/solubility of metals and nutrients in a Louisiana Mississippi River deltaic plain freshwater lake. Sci. Total Environ. 2006, 371, 334-343. [CrossRef]

34. Trefry, J.H.; Metz, S.; Trocine, R.P.; Nelsen, T.A. A Decline in Lead Transport by the Mississippi River. Science 1985, 230, 439-441. [CrossRef]

35. Corbett, R.D.; McKee, B.; Allison, M.A. Nature of decadal-scale sediment accumulation on the western shelf of the Mississippi River delta. Cont. Shelf Res. 2006, 26, 2125-2140. [CrossRef]

36. Trefry, J.H.; Presley, B.J. Heavy metal transport from the Mississippi River to the Gulf of Mexico. In Marine Pollutant Transfer; Windom, H.L., Duce, R.A., Eds.; Heath and Co., Lexington Books: Lexington, MA, USA, 1976; pp. 39-76.

37. Trefry, J.H.; Shokes, R.F. Chapter 4 History of Heavy-Metal Inputs to Mississippi Delta Sediments. In Elsevier Oceanography Series; Geyer, R.A., Ed.; Elsevier: Amsterdam, The Netherlands, 1981; Volume 27, pp. 193-208. [CrossRef]

38. Trefry, J.H.; Presley, B.J. Heavy Metals in Sediments from San Antonio Bay and the Northwest Gulf of Mexico. Environ. Geol. 1976, 1, 283-294. [CrossRef]

39. USEPA. US Environmental Protection Agency. EPA Takes Final Step in Phaseout of Leaded Gasoline. US Environmental Protection Agency Washington, DC: EPA's Web Archive; 1996. Available online: https:/ archive.epa.gov/epa/aboutepa/epa-takes-final-step-phaseout-leadedgasoline.html (accessed on 11 June 2020).

40. Mielke, H.W.; Anderson, J.C.; Berry, K.J.; Mielke, P.W., Jr.; Chaney, R.L.; Leech, M. Lead concentrations in inner-city soils as a factor in the child lead problem. Am. J. Public Health 1983, 73, 1366-1369. [CrossRef] [PubMed]

41. Mielke, H.W.; Dugas, D.; Mielke, P.W., Jr.; Smith, K.S.; Gonzales, C.R. Associations between soil lead and childhood blood lead in urban New Orleans and rural Lafourche Parish of Louisiana. Environ. Health Perspect. 1997, 105, 950-954. [CrossRef] [PubMed] 
42. Mielke, H.W.; Gonzales, C.R.; Powell, E.; Jartun, M.; Mielke, P.W. Nonlinear association between soil lead and blood lead of children in metropolitan New Orleans, Louisiana: 2000-2005. Sci. Total Environ. 2007, 388, 43-53. [CrossRef] [PubMed]

43. Mielke, H.W.; Powell, E.T.; Gonzales, C.R.; Mielke, P.W. Potential lead on play surfaces: Evaluation of the "PLOPS" sampler as a new tool for primary lead prevention. Environ. Res. 2007, 103, 154-159. [CrossRef]

44. Mielke, H.W.; Reagan, P.L. Soil is an important pathway of human lead exposure. Environ. Health Perspect. 1998, 106, 217-229. [CrossRef]

45. Laidlaw, M.A.S.; Filippelli, G.M. Resuspension of urban soils as a persistent source of lead poisoning in children: A review and new directions. Appl. Geochem. 2008, 23, 2021-2039. [CrossRef]

46. Laidlaw, M.A.S.; Mielke, H.W.; Filippelli, G.M.; Johnson, D.L.; Gonzales, C.R. Seasonality and Children's Blood Lead Levels: Developing a Predictive Model Using Climatic Variables and Blood Lead Data from Indianapolis, Indiana, Syracuse, New York, and New Orleans, Louisiana (USA). Environ. Health Perspect. 2005, 113, 793-800. [CrossRef]

47. Morrison, D.; Lin, Q.; Wiehe, S.; Liu, G.; Rosenman, M.; Fuller, T.; Wang, J.; Filippelli, G.M. Spatial relationships between lead sources and children's blood lead levels in the urban center of Indianapolis (USA). Environ. Geochem. Health 2013, 35, 171-183. [CrossRef]

48. Filippelli, G.M.; Adamic, J.; Nichols, D.; Shukle, J.; Frix, E. Mapping the Urban Lead Exposome: A Detailed Analysis of Soil Metal Concentrations at the Household Scale Using Citizen Science. Int. J. Env. Res. Public Health 2018, 15, 1531. [CrossRef]

49. DeLaune, R.D.; Reddy, C.N.; Patrick, W.H. Accumulation of Plant Nutrients and Heavy Metals through Sedimentation Processes and Accretion in a Louisiana Salt Marsh. Estuaries 1981, 4, 328-334. [CrossRef]

50. Weis, J.S.; Weis, P. Metal uptake, transport and release by wetland plants: Implications for phytoremediation and restoration. Environ. Int. 2004, 30, 685-700. [CrossRef] [PubMed]

51. Ye, S.; Laws, E.A.; Gambrell, R. Trace element remobilization following the resuspension of sediments under controlled redox conditions: City Park Lake, Baton Rouge, LA. Appl. Geochem. 2013, 28, 91-99. [CrossRef]

52. Michalec, B.K.; Lenart-Boroń, A.M.; Cupak, A.K.; Wałęga, A.S. The evaluation of heavy metal content in water and sediments of small reservoirs in light of various environmental quality regulations. J. Environ. Sci. Health Part A 2014, 49, 827-832. [CrossRef] [PubMed]

53. Dockery, D.T., III; Thompson, D.E. The Geology of Mississippi; University Press of Mississippi Jackson and Mississippi Department of Environmental Quality: Jackson, MS, USA, 2016; Volume 692, p. 751.

54. Surbeck, C.Q.; Davidson, G.R.; Wren, D.G. Long-term metal and arsenic mobility between wetlands and lakes: Variable histories within the same floodplain. Appl. Geochem. 2018, 96, 244-251. [CrossRef]

55. Howeler, R.H. The Oxygen Status of Lake Sediments. J. Environ. Qual. 1972, 1, 366-371. [CrossRef]

56. Calmano, W.; Hong, J.; Förstner, U. Binding and Mobilization of Heavy Metals in Contaminated Sediments Affected by $\mathrm{pH}$ and Redox Potential. Water Sci. Technol. 1993, 28, 223-235. [CrossRef]

57. Stumm, W.; Morgan, J.J. Aquatic Chemistry: Chemical Equilibria and Rates in Natural Waters; A Wiley-Interseience Publication, John Wiley \& Sons, INC: New York, NY, USA, 2012.

58. Riba, I.; García-Luque, E.; Blasco, J.; DelValls, T.A. Bioavailability of heavy metals bound to estuarine sediments as a function of $\mathrm{pH}$ and salinity values. Chem. Speciat. Bioavailab. 2003, 15, 101-114. [CrossRef]

59. Du Laing, G.; Rinklebe, J.; Vandecasteele, B.; Meers, E.; Tack, F.M.G. Trace metal behaviour in estuarine and riverine floodplain soils and sediments: A review. Sci. Total Environ. 2009, 407, 3972-3985. [CrossRef]

60. Wong, V.N.L.; Johnston, S.G.; Burton, E.D.; Bush, R.T.; Sullivan, L.A.; Slavich, P.G. Seawater-induced mobilization of trace metals from mackinawite-rich estuarine sediments. Water Res. 2013, 47, 821-832. [CrossRef]

61. Wang, Z.; Wang, Y.; Zhao, P.; Chen, L.; Yan, C.; Yan, Y.; Chi, Q. Metal release from contaminated coastal sediments under changing $\mathrm{pH}$ conditions: Implications for metal mobilization in acidified oceans. Mar. Pollut. Bull. 2015, 101, 707-715. [CrossRef]

62. Flowers, G.C.; Isphording, W.C. Heavy metal geochemistry of the Pontchartrain-Maurepas estuarine complex. Gulf Coast Association of Geological Societies and Gulf Coast Section of SEPM. Soc. Econ. AAPG Bulletin 1990, 74, 9. [CrossRef]

63. Tang, J.; Whittecar, G.R.; Johannesson, K.H.; Daniels, W.L. Potential contaminants at a dredged spoil placement site, Charles City County, Virginia, as revealed by sequential extraction. Geochem. Trans. 2004, 5, 49. [CrossRef] 
64. Piper, D.Z.; Ludington, S.; Duval, J.S.; Taylor, H.E. Geochemistry of bed and suspended sediment in the Mississippi river system: Provenance versus weathering and winnowing. Sci. Total Environ. 2006, 362, 179-204. [CrossRef] [PubMed]

65. Adams, C.A.; Andrews, J.E.; Jickells, T. Nitrous oxide and methane fluxes vs. carbon, nitrogen and phosphorous burial in new intertidal and saltmarsh sediments. Sci. Total Environ. 2012, 434, $240-251$. [CrossRef] [PubMed]

66. Mohajerin, T.J.; Helz, G.R.; Johannesson, K.H. Tungsten-molybdenum fractionation in estuarine environments. Geochim. Cosmochim. Acta 2016, 177, 105-119. [CrossRef]

67. Telfeyan, K.; Breaux, A.; Kim, J.; Cable, J.E.; Kolker, A.S.; Grimm, D.A.; Johannesson, K.H. Arsenic, vanadium, iron, and manganese biogeochemistry in a deltaic wetland, southern Louisiana, USA. Mar. Chem. 2017, 192, 32-48. [CrossRef]

68. Telfeyan, K.; Breaux, A.; Kim, J.; Kolker, A.S.; Cable, J.E.; Johannesson, K.H. Cycling of oxyanion-forming trace elements in groundwaters from a freshwater deltaic marsh. Estuar. Coast. Shelf Sci. 2018, 204, 236-263. [CrossRef]

69. Lane, R.R.; Day, J.W.; Thibodeaux, B. Water quality analysis of a freshwater diversion at Caernarvon, Louisiana. Estuaries 1999, 22, 327-336. [CrossRef]

70. Mitsch, W.J.; Day, J.W. Restoration of wetlands in the Mississippi-Ohio-Missouri (MOM) River Basin: Experience and needed research. Ecol. Eng. 2006, 26, 55-69. [CrossRef]

71. Snedden, G.A.; Cable, J.E.; Swarzenski, C.; Swenson, E. Sediment discharge into a subsiding Louisiana deltaic estuary through a Mississippi River diversion. Estuar. Coast. Shelf Sci. 2007, 71, 181-193. [CrossRef]

72. Kolker, A.S.; Miner, M.D.; Weathers, H.D. Depositional dynamics in a river diversion receiving basin: The case of the West Bay Mississippi River Diversion. Estuar. Coast. Shelf Sci. 2012, 106, 1-12. [CrossRef]

73. Das, A.; Justic, D.; Inoue, M.; Hoda, A.; Huang, H.; Park, D. Impacts of Mississippi River diversions on salinity gradients in a deltaic Louisiana estuary: Ecological and management implications. Estuar. Coast. Shelf Sci. 2012, 111, 17-26. [CrossRef]

74. Elsey-Quirk, T.; Graham, S.A.; Mendelssohn, I.A.; Snedden, G.; Day, J.W.; Twilley, R.R.; Shaffer, G.; Sharp, L.A.; Pahl, J.; Lane, R.R. Mississippi river sediment diversions and coastal wetland sustainability: Synthesis of responses to freshwater, sediment, and nutrient inputs. Estuar. Coast. Shelf Sci. 2019, 221, 170-183. [CrossRef]

75. Bridgeman, J.G. Understanding Mississippi Delta subsidence through stratigraphic and geotechnical analysis of a continuous Holocene core at a subsidence superstation. Tulane University School of Science and Engineering. 2018. Available online: https://search.proquest.com/openview/ c196964a9d9b3ba6ab76d51301b5c49c/1?pqorigsite=gscholar\&cbl=18750\&diss=y (accessed on 13 June 2020).

76. Allision, M.; Tulane University, New Orleans, Louisiana, United Sates. Personal communication, 2019.

77. Chamberlain, E.L.; Wallinga, J. Seeking enlightenment of fluvial sediment pathways by optically stimulated luminescence signal bleaching of river sediments and deltaic deposits. Earth Surf. Dyn. 2019, 7, 723-726. [CrossRef]

78. Hughes, J.E.T. A Geochronological and Stratigraphic Reconstruction of the Middle Barataria Bay Receiving Basin. Master's Thesis, Louisiana State University and Agricultural and Mechanical College, LSU Digital Commons, Baton Rouge, LA, USA, 2016. Available online: https://digitalcommons.lsu.edu/gradschool_ theses/4427 (accessed on 26 May 2020).

79. Bentley, S.J.; Xu, K.; Chen, Q. Data Report: Geological and Geotechnical Characterization for Lower Barataria Bay and Lower Breton Sound Diversion Receiving Basins; Coastal Studies Technical Report for the Water Institute of the Gulf; The Water Institute of the Gulf: Baton Rouge, LA, USA, 2015.

80. Bentley, S.J.; Xu, K.; Chen, Q. Geological and Geotechnical Characterization for Middle Barataria Bay and Middle Breton Sound Diversion Receiving Basins; Coastal Studies Technical Report for the Water Institute of the Gulf; The Water Institute of the Gulf: Baton Rouge, LA, USA, 2015.

81. Breaux, A.M. Utilization of Shallow Seismic, Resistivity Profiling, and Sediment Core Analyses for Identification of Semi-Permeable Sediments that Act as Conduits for Submarine Groundwater Discharge, Barataria Bay, Louisiana. Master's Thesis, (10143955). Tulane University, New Orleans, LU, USA, 2015. Available online: https://search.proquest.com/openview/662a4af13ec39757fa0fc95e75c36eef/1?pqorigsite= gscholar\&cbl=18750\&diss $=y$ (accessed on 20 May 2020). 
82. Meselhe, E.A.; Georgiou, I.; Allison, M.A.; McCorquodale, J.A. Numerical modeling of hydrodynamics and sediment transport in lower Mississippi at a proposed delta building diversion. J. Hydrol. 2013, 472-473, 340-354. [CrossRef]

83. CPRA. Coastal Restoration Authority of Louisiana. Mid-Barataria and Mid-Breton Sediment Diversions: Overview and Frequently asked Questions; 2018. Available online: http://coastal.la.gov/wp-content/ uploads/2018/03/OVERVIEW_FAQs_Mid-Barataria-and-Mid-Breton-Sediment-Diversions.pdf (accessed on 13 June 2020).

84. USACE. United States Army Corps of Engineers. Environmental Impact Statement: Mid-Barataria Sediment Diversion. 2020. Available online: https://www.mvn.usace.army.mil/Missions/Regulatory/Permits/MidBarataria-Sediment-Diversion-EIS (accessed on 8 June 2020).

85. CPRA. Coastal Restoration Authority of Louisiana. Mississippi River Mid-Basin Sediment Diversion Program: Timeline. 2020. Available online: http://coastal.la.gov/our-work/key-initiatives/\%20diversion\%20program/timeline/ (accessed on 13 June 2020).

86. Thorne, C.R.; Harmar, O.P.; Wallerstein, N. Sediment Transport in the Lower Mississippi River; Nottingham University (United Kingdom) Department of Geography: Nottingham, UK, 2000.

87. Rosenheim, B.E.; Roe, K.M.; Roberts, B.J.; Kolker, A.S.; Allison, M.A.; Johannesson, K.H. River discharge influences on particulate organic carbon age structure in the Mississippi/Atchafalaya River System. Glob. Biogeochem. Cycles 2013, 27, 154-166. [CrossRef]

88. Hijma, M.P.; Shen, Z.; Törnqvist, T.E.; Mauz, B. Late Holocene evolution of a coupled, mud-dominated delta plain-chenier plain system, coastal Louisiana, USA. Earth Surf. Dyn. 2017, 5, 689-710. [CrossRef]

89. Tessier, A.; Campbell, P.G.C.; Bisson, M. Sequential extraction procedure for the speciation of particulate trace metals. Anal. Chem. 1979, 51, 844-851. [CrossRef]

90. Willis, S.S.; Johannesson, K.H. Controls on the geochemistry of rare earth elements in sediments and groundwaters of the Aquia aquifer, Maryland, USA. Chem. Geol. 2011, 285, 32-49. [CrossRef]

91. Presley, B.J.; Trefry, J.H.; Shokes, R.F. Heavy metal inputs to Mississippi Delta sediments. Water Air Soil Pollut. 1980, 13, 481-494. [CrossRef]

92. Swarzenski, P.W.; Baskaran, M.; Rosenbauer, R.J.; Orem, W.H. Historical trace element distribution in sediments from the Mississippi River delta. Estuaries Coasts 2006, 29, 1094-1107. [CrossRef]

93. Garbarino, J.R.; Hayes, H.C.; Roth, D.A.; Antweiler, R.C.; Brinton, T.I.; Taylor, H.E. Heavy metals in the Mississippi River. Geol. Surv. Circ. 1996, 1133, 53-72. Available online: https://pubs.usgs.gov/circ/circ1133/ heavy-metals.html (accessed on 21 January 2020).

94. Filippelli, G.M.; Laidlaw, M.A.S.; Latimer, J.C.; Raftis, R. Urban lead poisoning and medical geology: An unfinished story. GSA Today 2005, 15, 4-11. [CrossRef]

95. Fitzpatrick, M.L.; Long, D.T.; Pijanowski, B.C. Exploring the effects of urban and agricultural land use on surface water chemistry, across a regional watershed, using multivariate statistics. Appl. Geochem. 2007, 22, 1825-1840. [CrossRef]

96. Huser, B.; Köhler, S.; Wilander, A.; Johansson, K.; Fölster, J. Temporal and spatial trends for trace metals in streams and rivers across Sweden (1996-2009). Biogeosciences 2011, 8, 1813-1823. [CrossRef]

97. Mielke, H.W.; Zahran, $\mathrm{S}$. The urban rise and fall of air lead $(\mathrm{Pb})$ and the latent surge and retreat of societal violence. Environ. Int. 2012, 43, 48-55. [CrossRef]

98. Han, L.; Gao, B.; Hao, H.; Zhou, H.; Lu, J.; Sun, K. Lead contamination in sediments in the past 20 years: A challenge for China. Sci. Total Environ. 2018, 640-641, 746-756. [CrossRef]

99. Stets, E.G.; Lee, C.J.; Lytle, D.A.; Schock, M.R. Increasing chloride in rivers of the conterminous U.S. and linkages to potential corrosivity and lead action level exceedances in drinking water. Sci. Total Environ. 2018, 613-614, 1498-1509. [CrossRef]

100. Viers, J.; Dupré, B.; Gaillardet, J. Chemical composition of suspended sediments in World Rivers: New insights from a new database. Sci. Total Environ. 2009, 407, 853-868. [CrossRef]

101. Reiman, J.H.; Xu, Y.J.; He, S.; DelDuco, E.M. Metals geochemistry and mass export from the Mississippi-Atchafalaya River system to the Northern Gulf of Mexico. Chemosphere 2018, 205, 559-569. [CrossRef]

102. Shiller, A.M. Dissolved trace elements in the Mississippi River: Seasonal, interannual, and decadal variability. Geochim. Cosmochim. Acta 1997, 61, 4321-4330. [CrossRef] 
103. Stolpe, B.; Guo, L.; Shiller, A.M.; Hassellöv, M. Size and composition of colloidal organic matter and trace elements in the Mississippi River, Pearl River and the northern Gulf of Mexico, as characterized by flow field-flow fractionation. Mar. Chem. 2010, 118, 119-128. [CrossRef]

104. Davis, J.A.; Gloor, R. Adsorption of dissolved organics in lake water by aluminum oxide. Effect of molecular weight. Environ. Sci. Technol. 1981, 15, 1223-1229. [CrossRef]

105. Vermeer, A.W.P.; Koopal, L.K. Adsorption of Humic Acids to Mineral Particles. 2. Polydispersity Effects with Polyelectrolyte Adsorption. Langmuir 1998, 14, 4210-4216. [CrossRef]

106. Evanko, C.R.; Dzombak, D.A. Surface Complexation Modeling of Organic Acid Sorption to Goethite. J. Colloid Interface Sci. 1999, 214, 189-206. [CrossRef] [PubMed]

107. Filius, J.D.; Lumsdon, D.G.; Meeussen, J.C.L.; Hiemstra, T.; Van Riemsdijk, W.H. Adsorption of fulvic acid on goethite. Geochim. Cosmochim. Acta 2000, 64, 51-60. [CrossRef]

108. Liang, L.; Luo, L.; Zhang, S. Adsorption and desorption of humic and fulvic acids on $\mathrm{SiO} 2$ particles at nanoand micro-scales. Colloids Surf. A Physicochem. Eng. Asp. 2011, 384, 126-130. [CrossRef]

109. Chotzen, R.A.; Polubesova, T.; Chefetz, B.; Mishael, Y.G. Adsorption of soil-derived humic acid by seven clay minerals: A systematic study. Clays Clay Miner. 2016, 64, 628-638. [CrossRef]

110. Larocque, A.C.L.; Rasmussen, P.E. An overview of trace metals in the environment, from mobilization to remediation. Environ. Geol. 1998, 33, 85-91. [CrossRef]

111. Meador, J. Rationale and Procedures for Using the Tissue-Residue Approach for Toxicity Assessment and Determination of Tissue, Water, and Sediment Quality Guidelines for Aquatic Organisms. Hum. Ecol. Risk Assess. Int. J. 2006, 12, 1018-1073. [CrossRef]

112. Zhang, Z.; Wang, J.J.; Ali, A.; DeLaune, R.D. Heavy metal distribution and water quality characterization of water bodies in Louisiana's Lake Pontchartrain Basin, USA. Environ. Monit. Assess. 2016, 188, 628. [CrossRef] [PubMed]

113. Mirlean, N.; Ferraz, A.H.; Seus-Arrache, E.R.; Andrade, C.F.F.; Costa, L.P.; Johannesson, K.H. Mercury and selenium in the Brazilian subtropical marine products: Food composition and safety. J. Food Compos. Anal. 2019, 84, 103310. [CrossRef]

114. Mitra, S.; Sudarshan, M.; Jonathan, M.P.; Sarkar, S.K.; Thakur, S. Spatial and seasonal distribution of multi-elements in suspended particulate matter (SPM) in tidally dominated Hooghly river estuary and their ecotoxicological relevance. Environ. Sci. Pollut. Res. 2020, 27, 12658-12672. [CrossRef] [PubMed]

115. Quintana, G.; Mirlean, N.; Costa, L.P.; Johannesson, K. Mercury distributions in sediments of an estuary subject to anthropogenic hydrodynamic alterations (Patos Estuary, Southern Brazil). Environ. Monit. Assess. 2020, 192, 266. [CrossRef]

116. Davranche, M.; Bollinger, J.; Bril, H. Effect of reductive conditions on metal mobility from wasteland solids: An example from the Mortagne-du-Nord site (France). Appl. Geochem. 2003, 18, 383-394. [CrossRef]

117. Hering, J.G.; Kneebone, P.E. Biogeochemical controls on arsenic occurrence and mobility in water supplies. In Environmental Chemistry of Arsenic; Frankenberger, W.T., Ed.; Marcel Dekker: New York, NY, USA, 2002; pp. 155-181.

118. Johannesson, K.H.; Yang, N.; Trahan, A.S.; Telfeyan, K.; Jade Mohajerin, T.; Adebayo, S.B.; Akintomide, O.A.; Chevis, D.A.; Datta, S.; White, C.D. Biogeochemical and reactive transport modeling of arsenic in groundwaters from the Mississippi River delta plain: An analog for the As-affected aquifers of South and Southeast Asia. Geochim. Cosmochim. Acta 2019, 264, 245-272. [CrossRef]

119. Osipov, V.I. Density of clay minerals. Soil Mech. Found. Eng. 2012, 48, 231-240. [CrossRef]

120. USEPA. US Environmental Protection Agency. Edition of the Drinking Water Standards and Health Advisories; EPA's Web Archive, EPA 822-F-18-001; Office of Water; US Environmental Protection Agency: Washington, DC, USA, 2018; Available online: https:/www.epa.gov/sites/production/files/2018--03/ documents/dwtable2018.pdf (accessed on 6 July 2020).

121. USEPA. US Environmental Protection Agency. Framework For Developing Suspended and Bedded Sediment (Sabs) Water Quality Criteria; EPA 822/R-06/001. U.S. EPA; Office of Water; Office of Research and Development: Washington, DC, USA, 2006; Available online: https://cfpub.epa.gov/ncea/risk/recordisplay.cfm?deid=164423 (accessed on 6 July 2020).

122. Dallinger, R.; Prosi, F.; Segner, H.; Back, H. Contaminated food and uptake of heavy metals by fish: A review and a proposal for further research. Oecologia 1987, 73, 91-98. [CrossRef] 
123. Schmitt, C.J. Concentrations of Arsenic, Cadmium, Copper, Lead, Selenium, and Zinc in Fish from the Mississippi River Basin, 1995. Environ. Monit. Assess. 2004, 90, 289-321. [CrossRef]

124. Rogowski, D.L.; Soucek, D.J.; Levengood, J.M.; Johnson, S.R.; Chick, J.H.; Dettmers, J.M.; Pegg, M.A.; Epifanio, J.M. Contaminant concentrations in Asian carps, invasive species in the Mississippi and Illinois Rivers. Environ. Monit. Assess. 2009, 157, 211-222. [CrossRef]

(C) 2020 by the authors. Licensee MDPI, Basel, Switzerland. This article is an open access article distributed under the terms and conditions of the Creative Commons Attribution (CC BY) license (http://creativecommons.org/licenses/by/4.0/). 